\title{
3 Tesla magnetic resonance imaging of the nasal cavities, paranasal sinuses and adjacent anatomical structures in 13 healthy horses
}

\author{
Joachim Kaminsky and Astrid Bienert-Zeit (shared first authorship), Maren Hellige and Bernhard Ohnesorge \\ Equine Clinic, University of Veterinary Medicine Hannover, Foundation, Hannover
}

\begin{abstract}
Summary: The nasal cavities and paranasal sinuses of 13 healthy horses of different breeds aged 4 to 20 years were examined under general anaesthesia using 3 Tesla magnetic resonance imaging (MRI). Horses were positioned in dorsal recumbency. T2-weighted images were obtained in a transversal and dorsal orientation as well as $\mathrm{Tl}$-weighted images and proton density weighted images in a transversal orientation. Images were examined for the visualization of the nasal cavities, paranasal sinuses and adjacent anatomical structures. Differences and similarities in the appearance of the anatomical structures in the different MRI sequences as well as inter-and intraindividual differences and similarities were documented. In four selected planes of the transversal oriented T2-weighted images the thickness of the venous plexus of the nasal mucosa of the left and right side could be measured in 12 horses. Planes and measurement points were chosen by defined anatomical landmarks. Visualized anatomical structures were well delineated in 3 Tesla magnetic resonance images. Inter- and intraindividual differences were present in the appearance of the nasal septum, the venous plexus of the nasal mucosa, the infraorbital canal and other structures in the examined healthy horses. The thickness of the venous plexus of the nasal mucosa was measured with up to $25.5 \mathrm{~mm}$ lining the spiral lamella of the ventral concha and the nasal meatus were entirely occluded by the nasal mucosa in some horses. Knowledge of the physiological appearance of anatomical structures in 3 Tesla MRI is fundamental in the use of this imaging modality as a diagnostic instrument. Interindividual differences in the appearance of anatomical structures are present in healthy horses and therefore not to be interpreted as pathologies in clinical cases.
\end{abstract}

Keywords: MRI / horse / paranasal sinuses / nasal mucosa / upper airways / 3 Tesla

\section{Darstellung der Nasenhöhlen, Nasennebenhöhlen und angrenzender anatomischer Strukturen im 3 Tesla-Magnetresonanz-} tomographen bei 13 gesunden Pferden

Die Nasen- und Nasenebenhöhlen von 13 gesunden Pferden unterschiedlicher Rasse im Alter von 4 bis 20 Jahren wurden in Allgemeinanästhesie mit einem Magnetresonanztomographen der Feldstärke 3 Tesla untersucht. Die Pferde wurden in Rückenlage positioniert. Es wurden transversal und dorsal ausgerichtete Aufnahmen in einer T2-Gewichtung sowie transversal ausgerichtete Aufnahmen in einer T1 - und einer Protonengewichtung erstellt. Die Bilder wurden systematisch betrachtet und ausgewertet. Im Rahmen der Auswertung wurde besonders auf die Darstellung der anatomischen Strukturen im Bereich der Nasen- und Nasennebenhöhlen geachtet. Im Zuge der Betrachtung wurde die Darstellung der verschiedenen anatomischen Strukturen in den unterschiedlichen Aufnahmesequenzen beurteilt und Ähnlichkeiten und Unterschiede zwischen den Sequenzen dokumentiert. Auch inter- und intraindividuelle Unterschiede und Übereinstimmungen wurden dokumentiert. In vier ausgewählten Schnittebenen der transversal orientierten T2-gewichteten Sequenz wurde die Dicke der Nasenschleimhaut und ihrer Venenplexus der linken und rechten Seite bei 12 Pferden gemessen. Die vier Schnittebenen und die Messpunkte wurden anhand von definierten anatomischen Strukturen ausgewählt. Die dargestellten anatomischen Strukturen waren in der 3 Tesla Magnetresonanztomographie gut zu differenzieren. Bei den 13 gesunden Pferden bestanden inter- und intraindividuelle Unterschiede im Bereich des Nasenseptums, der Venenplexus der Nasenschleimhaut, der Canales infraorbitales und weiterer anatomischer Strukturen. Die Messung der Venenplexus der Nasenschleimhaut, welche der Spirallamelle der ventralen Nasenmuschel aufliegen, ergab Dicken von bis zu 25,5 mm. Die Nasengänge waren in einigen Bereichen durch die Schwellung der Venenplexus vollständig verschlossen. Die erworbenen Kenntnisse über die Darstellung anatomischer Strukturen im Bereich des Kopfes gesunder Pferde in der 3 Tesla-Magnetresonanztomographie zeigt einen diagnostischen Mehrwert dieser Technik auf. Eine entscheidende Bedeutung haben die dargestellten inter- und intraindividuellen Unterschiede bei gesunden Pferden, wenn zukünftig pathologische Veränderungen beim erkrankten Pferd beurteilt werden sollen.

Schlüsselwörter: MRT / Pferd / Sinus paranasales / Nasenschleimhaut / obere Atemwege / Nasennebenhöhlen / 3 Tesla

Correspondence: Joachim Kaminsky, Dr. Astrid Bienert-Zeit, University of Veterninary Medicine Hannover, Clinic for Horses Bünteweg 9 , 30559 Hannover, Germany, E-mail: joachim-kaminsky@t-online.de / astrid.bienert@tiho-hannover.de

Citation: Kaminsky J., Bienert-Zeit A., Hellige M., Ohnesorge B. (2014) 3 Tesla magnetic resonance imaging of the equine nasal cavities, paranasal sinuses and adjacent anatomical structures in 13 healthy horses. Pferdeheilkunde 30, 413-431

\section{Introduction}

High-field magnetic resonance imaging (MRI) becomes more readily available in equine veterinary medicine (Arencibia et al. 2000, Gerlach and Gerhards 2008, Gerlach et al. 2009, Garrett et al. 2010, Cavalleri et al. 2013). With the technical progress in MRI magnets with field strengths of 3 Tesla become available in equine veterinary medicine (Gutierrez-Crespo et al. 2013, Hontoir et al. 2013). Higher field strengths bring along new possibilities, advantages in image acquisition like higher resolutions, thinner slices or shorter acquisition times in some sequences but also difficulties (Merkle and Dale 2006, Chang et al. 2008). The region of the equine nasal cavities, the paranasal sinuses and their communication ways have been described in MRI with lower field strengths (Arencibia et al. 2000, Gerlach et al. 2009). The aim of the present study was to utilize the advantages of 3 Tesla MRI to acquire high 
quality images of the equine nasal cavities and paranasal sinuses to describe the normal appearance of anatomical structures in this region in live and healthy horses to present a basis for clinicians in the interpretation of clinical cases.

\section{Materials and methods}

Thirteen healthy, horses of different breeds (7 Warmbloods, 2 Arabian thoroughbreds, 3 Standardbreds, 1 Andalusian) were used to acquire 3 Tesla magnetic resonance (MR) images. The group of horses was composed of 8 mares, 4 geldings and 1 stallion. The age of the horses ranged from 4 to 20 years (mean \pm SD, $11.6 \pm 6.5$ ). All horses were healthy and showed no signs of any disease related to the nasal cavities or the paranasal sinuses. Studies were approved by the Lower Saxony State Office for Consumer Protection and Food Safety (File reference:33.9-42502-04-11/0592). Magnetic resonance imaging was performed with the horses under general anaesthesia. The horses were positioned in dorsal recumbency on a non-stationary table cushioned by an inflatable mattress.

Surface coils (Philips SENSETM FlexM ${ }^{\circledR}$ and Philips SENSETM FlexL ${ }^{\circledR}$; Philips Medical Systems, Best, The Netherlands) were positioned around the region of interest and the head fixed in position with a vacuum cushion. MRI was performed with a Philips Achieva ${ }^{\mathrm{TM}}$ 3.0TX-Series ${ }^{\circledR}$ (Philips Medical Systems, Best, The Netherlands). In all horses T2weighed (T2w) images were obtained in dorsal and transverse planes. Proton density weighted (PDw) images were obtained in transverse planes. T1-weighted ( $T 1 \mathrm{w}$ ) images were obtained as a 3D-dataset so that dorsal and transverse planes could be reproduced using multiplanar recon- struction. Transverse planes were oriented perpendicular and dorsal planes parallel to the hard palate. The field of view from caudal to rostral for all horses ranged from 260 to $300 \mathrm{~mm}$ (mean \pm SD; $277.6 \mathrm{~mm} \pm 8.3 \mathrm{~mm}$ ) in dorsally oriented sequences and from 217 to $300 \mathrm{~mm}$ (mean \pm SD; $245.1 \mathrm{~mm} \pm 27.0 \mathrm{~mm}$ ) in transverse oriented studies. The rest of the MR examinations were performed with the same settings for each horse (Tab. 1). In all horses and modalities it was attempted to picture the animal's head from the eyes to the first premolar teeth.

The acquired images were examined for the visualization of depicted anatomical structures. The images were viewed one by one from caudal to rostral in transverse oriented studies and dorsal to ventral in dorsally oriented studies. Special attention was given to the most prominent and completely pictured anatomical structures like the ethmoid bone, the paranasal sinuses, the nasomaxillary aperture, the infraorbital canal with its content, the nasal septum, the venous plexus of the nasal mucosa and the maxillary premolar and molar teeth.

Differences and similarities between the different imaging techniques were assessed. Interindividual differences and similarities of the aforementioned anatomical structures between the 13 horses were documented as well as intraindividual differences in a right-left comparison. Furthermore the thickness of the nasal mucosa with its venous plexus was measured in defined places in selected T2w transverse images. For each horse four slices from different levels were chosen by defined anatomical landmarks. (Fig. 1 to 4).

The thickness of the mucosa and venous plexus lining the nasal septum in the four slices were all measured at the level

Fig. la schematic image of Plane 1 for measurement positioned immediately rostral to the eyes; $\mathbf{b}$ : image section of a T2w MR image from Plane 1, thickness of the mucosa with its venous plexus around the nasal septum was measured at the level of the middle nasal meatus (red lines).

a: schematische Darstellung der Ebene 1 für Messungen, direkt rostral der Augäpfel gelegen; $\boldsymbol{b}$ : Bildausschnitt eines T2-gewichteten Schnittbildes der Ebene 1, die Dicke der Nasenschleimhaut mit ihren Venenplexus wurde im Bereich des Nasenseptums auf Höhe der mittleren Nasengänge gemessen (rote Linien)

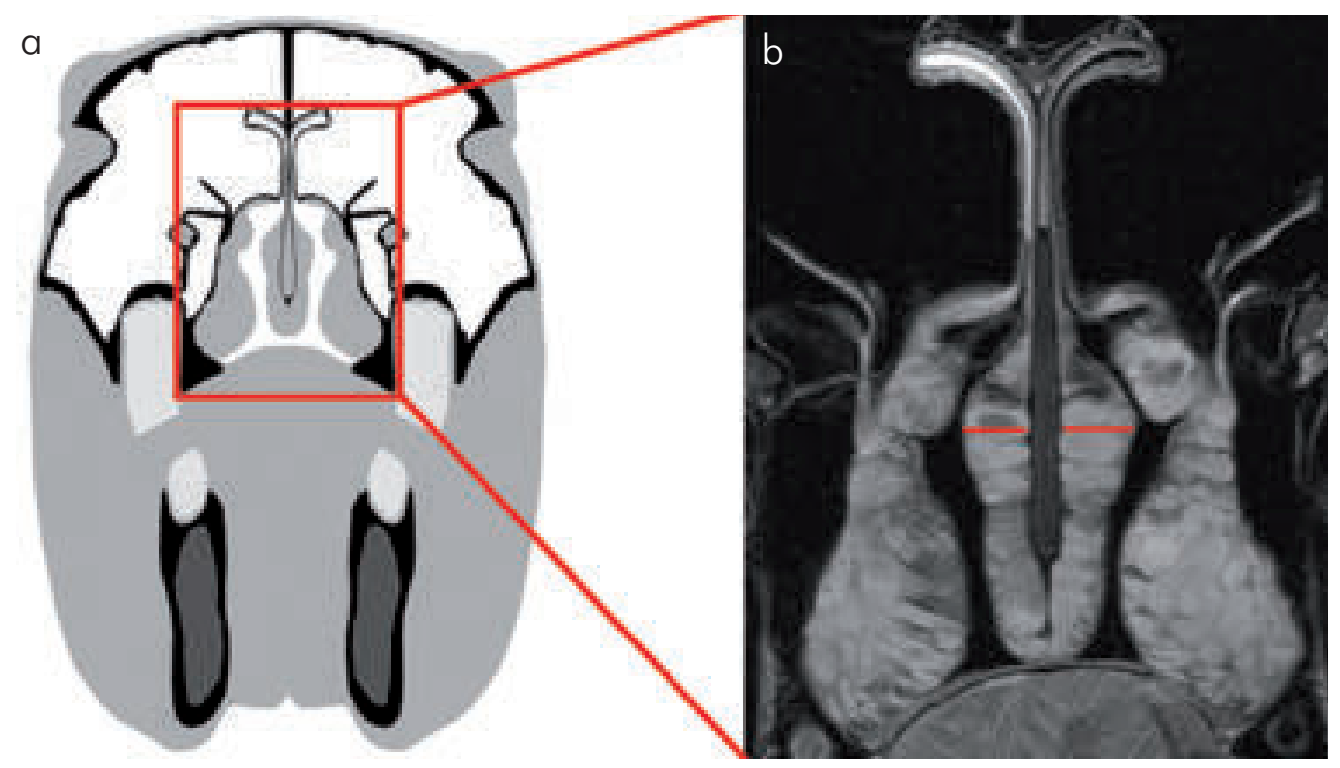

Table 1 MRI settings / MRT-Einstellwerte

\begin{tabular}{llllllll}
\hline Sequence & Orientation & Matrix & TR $(\mathrm{ms})$ & TE $(\mathrm{ms})$ & NSA & ST $(\mathrm{mm})$ & ISS $(\mathrm{mm})$ \\
\hline T2w TSE & dorsal & $800 \times 800$ & 3000 & 80 & 2 & 4.0 & 0.4 \\
T2w TSE & transverse & $1024 \times 1024$ & 4500 & 80 & 2 & 4.0 & 1.0 \\
T1w 3D & dorsal (3D) & $720 \times 720$ & 8 & 4 & 2 & 0.9 & 0.0 \\
PDw & transverse & $960 \times 960$ & 8300 & 30 & 2 & 4.0 & 0.4 \\
\hline
\end{tabular}

$\mathrm{TR}=$ time to repetition; TE = echo time; NSA = number of signal averages; $\mathrm{ST}=$ slice thickness; ISS = inter-slice spacing 
Fig. $2 a$ schematic image of Plane 2 for measurement, positioned on the level of the nasomaxillary aperture, a 'hook' (arrow heads) (Brinkschulte (2012) that was protruding dorsally from the spiral lamella of the dorsal concha in all horses was used as an anatomical landmark; $b$ : image section of a T2w MR image from Plane 2, thikkness of the mucosa and venous plexus lining the nasal septum (red lines) and the ventral concha was measured (green lines), thikkness along the middle nasal meatus was measured medial (dm, vm) and lateral (dl, vl). a: schematische Darstellung der Ebene 2 für Messungen, auf Höhe der Apertura nasomaxilla-

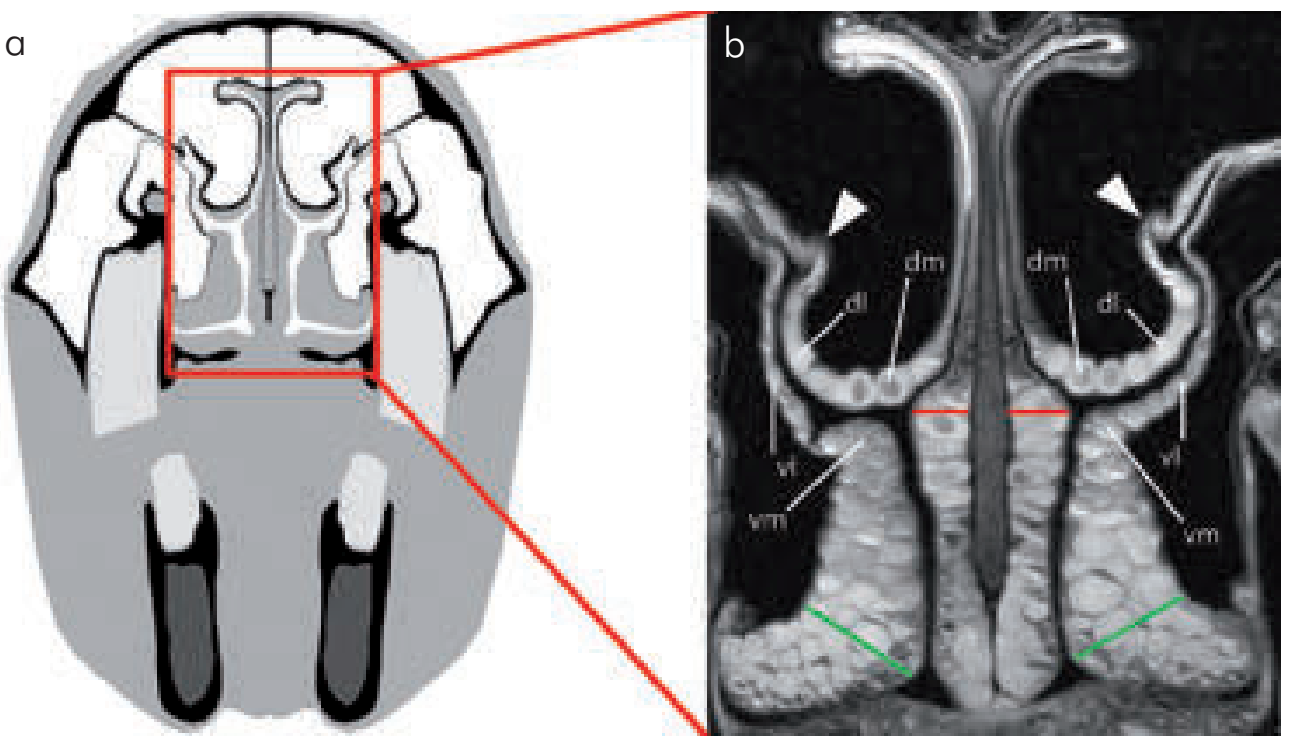
ris gelegen, ein "Vorsprung" (Pfeilspitzen) (Brinkschulte (2012)) der bei allen Pferden von der Spirallamelle der dorsalen Nasenmuschel nach dorsal abging, wurde als anatomischer Orientierungspunkt genutzt; b: Bildausschnitt eines T2-gewichteten Schnittbildes der Ebene 2, die Dikke der Nasenschleimhaut mit ihren Venenplexus wurde im Bereich des Nasenseptums (rote Linien) und der ventralen Nasenmuschel (grüne Linien) gemessen, zusätzlich wurde die Dicke entlang der mittleren Nasengänge medial (dm, vm) und lateral (dl, vl) gemessen.

Fig. 3a Schematic image of Plane 3 for measurement, positioned on the level of the nasomaxillary aperture, where the 'hook' (arrow heads, Brinkschulte 2012) starts to extend mediodorsally; $\mathbf{b}$ : image section of a T2w MR image from Plane 3, thickness of the mucosa and venous plexus lining the nasal septum (red lines) and the ventral concha was measured (green lines) a: Ebene 3 auf Höhe der Apertura nasomaxillaris, an dem Punkt, an dem der "Vorsprung" (Pfeilspitzen, Brinkschulte 2012)) sich nach mediodorsal ausweitet; $\boldsymbol{b}$ : Bildausschnitt eines T2-gewichteten Schnittbildes der Ebene 3, die Dikke der Nasenschleimhaut mit ihren Venenplexus wurde im Bereich des Nasenseptums (rote Linien) und der ventralen Nasenmuschel (grüne Linien) gemessen.

Fig. 4a Schematic image of Plane 4 for measurement, positioned on the level of the infraorbital foramen; b: image section of a T2w MR image from Plane 4, thickness of the mucosa and venous plexus lining the nasal septum (red lines) and the ventral concha was measured (green lines).

a: schematische Darstellung der Ebene 4 für Messungen, auf der Foramina infraorbitalia gelegen, b: Bildausschnitt eines T2gewichteten Schnittbildes der Ebene 4, die Dicke der Nasenschleimhaut mit ihren Venenplexus wurde im Bereich des Nasenseptums (rote Linien) und der ventralen Nasenmuschel (grüne Linien) gemessen.
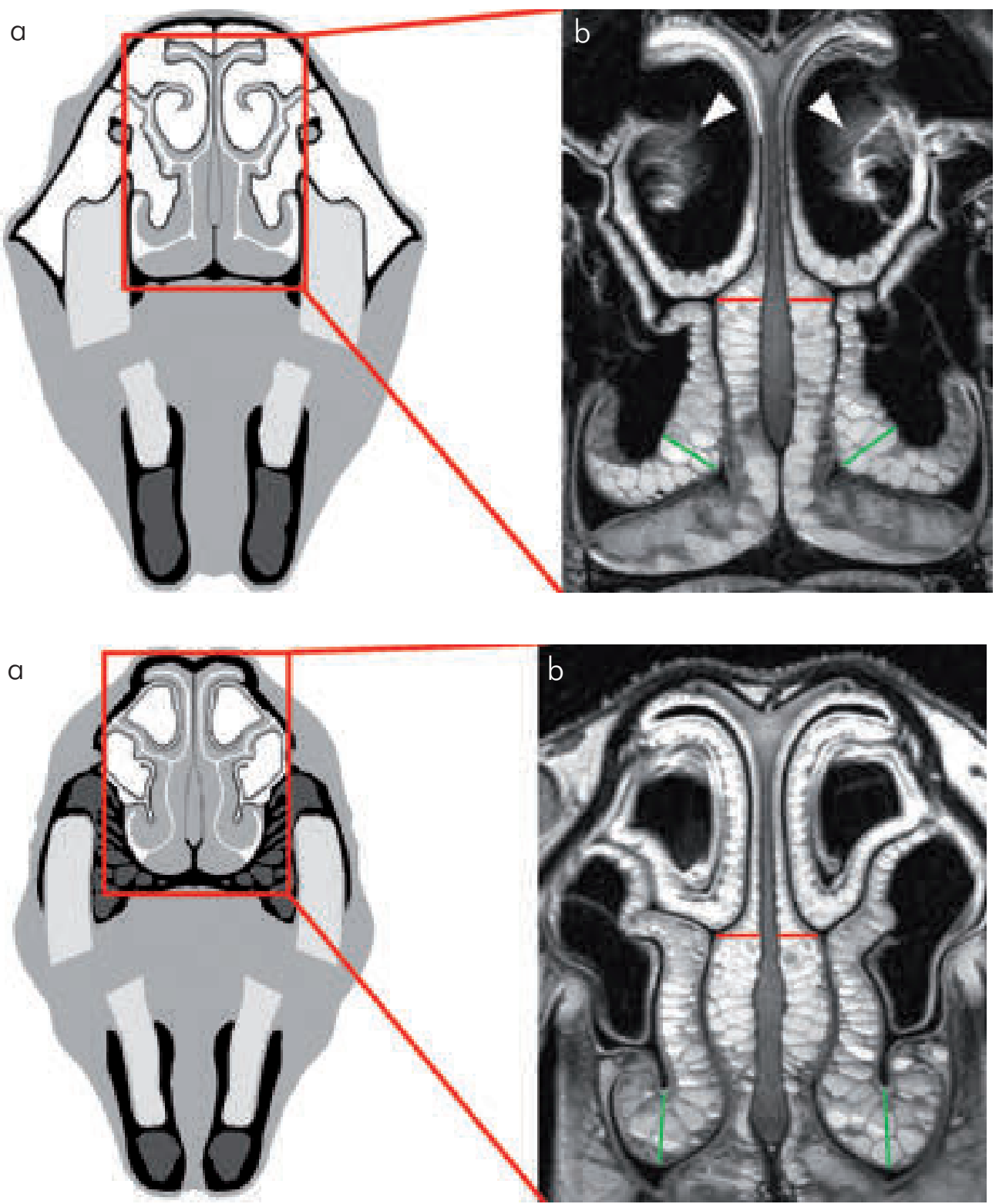
Fig. 5 T2w MRI picture; Ethmoid bone at the level of the eyes; delicately branched turbinalia (arrow), bright fluid inside the dorsal nasal meatus (arrow head), blurred appearance of the ventral edges of the ethmoid bone.

T2-gewichtetes MRT Schnittbild; Siebbein auf der Höhe der Augäpfel; fein verzweigte Turbinalia (Pfeil), signalreiche Flüssigkeit innerhalb des dorsalen Nasenganges (Pfeilspitze), verwaschenes Erscheinungsbild der ventralen Anteile des Siebbeins

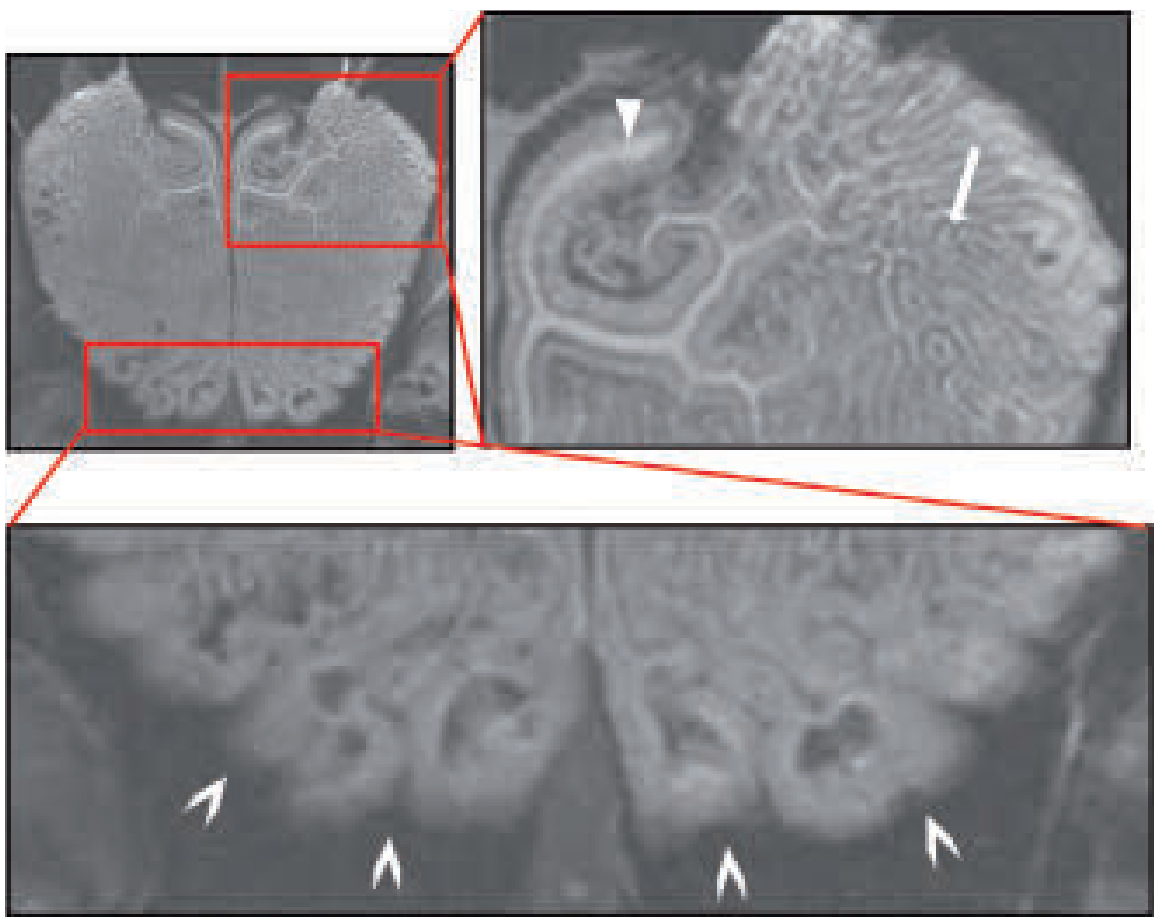

Fig. 6 T2w MRI picture; conchofrontal sinus (white spot) at the level of the M3; thin bright mucosa (1), signal free frontal bone plate (2), skin (3)

T2-gewichtetes MRT-Schnittbild, Sinus conchofrontalis (weißer Punkt) auf der Höhe des M3 gelegen; dünne signalreiche Schleimhaut (1), signallose Knochenplatte des Os frontale (2), Haut (3)

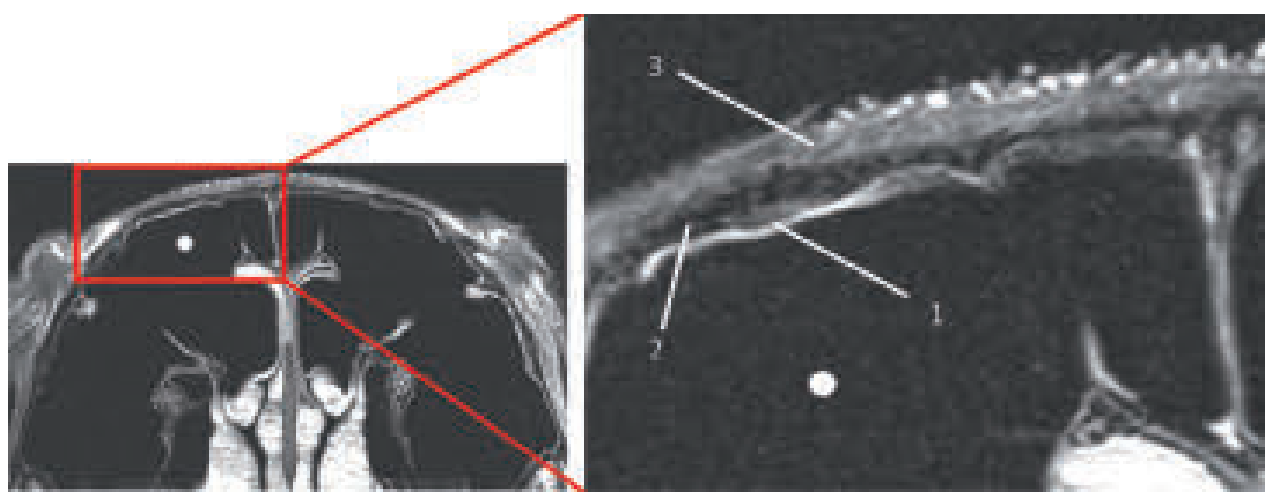

Fig. 7 T2w MRI picture; ventral conchal sinus at the level of the M2, bright fluid inside the ventral conchal sinus (arrow heads), fluids are located dorsally due to positioning of the horse in the MR scanner T2-gewichtetes MRT-Schnittbild, Sinus conchae ventralis auf Höhe des M2 gelegen, signalreiche Flüssigkeit im Sinus conchae ventralis (Pfeilspitzen), die Flüssigkeit steht aufgrund der Lagerung des Pferdes dorsal.

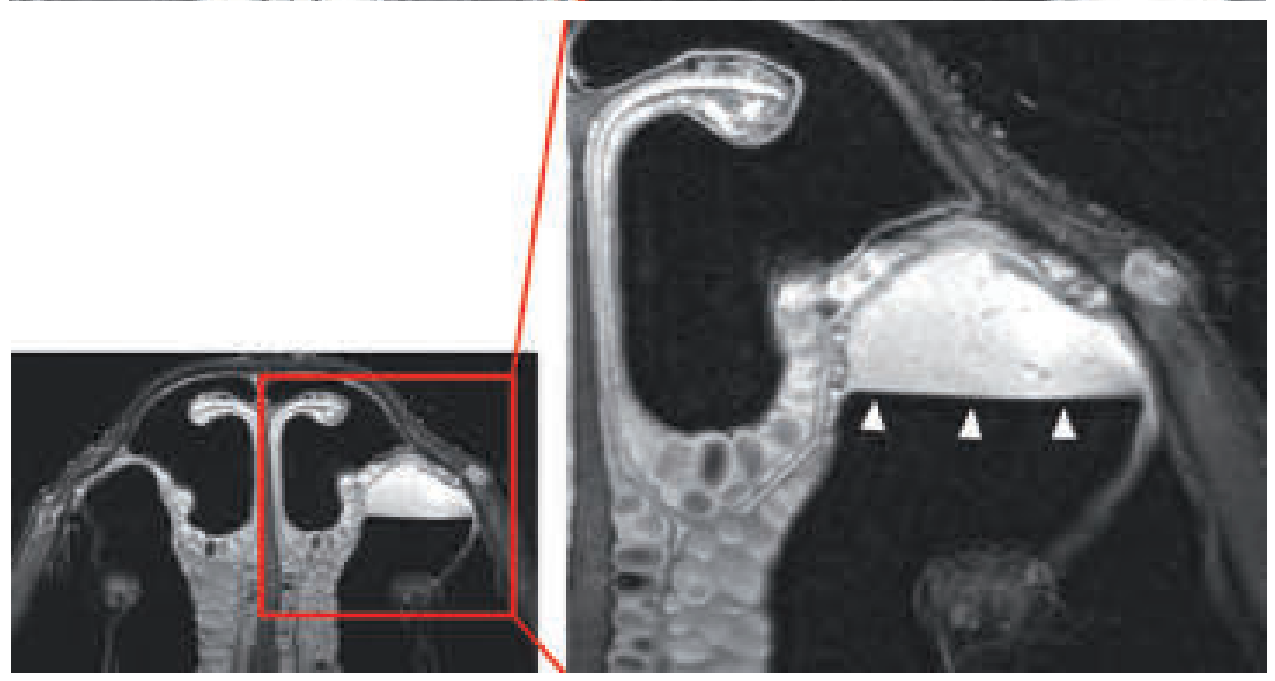

of the middle nasal meatus (Fig. 1 to 4 , red lines) at the thikkest point in a line perpendicular to the nasal septum. The thickness of the mucosa and venous plexus lining the ventral concha were measured at the apex of the spiral lamella protruding medioventrally (Fig. 2 and 3, green lines). The thickest point of the mucosa lining the apex was measured. In Plane 4 the measurements were oriented from the apex of the spiral lamella to the most ventral point of the ventral nasal meatus (Fig. 4, green lines). In Plane 2 the thicknesses of the venous plexus lining the dorsal concha and the ventral concha were measured at the junction of the common and middle nasal meatus and again at a point lying half the way between the aforementioned junction and a 'hook' protruding dorsally from the spiral lamella of the dorsal concha (Fig. 2). For all measurements the right side and the left side were measured. Review and measurements of all images were performed using efilm Workstation ${ }^{\circledR}$ 1.5.3 imaging software (eFilm Medical, Toronto, Canada). 


\section{Statistical analysis}

Data collection was performed in spreadsheets using the software Office Excel $2003^{\circledR}$ (Microsoft Corporation, Redmond, WA, USA) and descriptive statistics were applied.

\section{Results}

MRI examinations of the selected anatomical region were possible in all 13 horses. Examination time ranged from 90 to $104 \mathrm{~min}$ (mean $100 \mathrm{~min}$ ). The images of one horse had to be excluded from measurements because of movement artefacts which made accurate measurements impossible. The different anatomical structures appeared as follows.

\section{The ethmoid bone}

In the centre of the ethmoid bone the mucosal layer covering the thin turbinalia could be seen as thin bright lines. Especially in the T2w sequences with a high resolution the ethmoid labyrinth could be seen as a fine branched meshwork of small channels (Fig. 5). The rostral and ventral edges of the ethmoid bone had a blurred appearance in all horses and sequences so that the described branched meshwork could not be made out.

\section{The paranasal sinuses}

The conchofrontal, caudal maxillary, rostral maxillary and ventral conchal sinus were all visible as a signal free space lined by a thin bright line of mucosa (Fig. 6). On the inner surface of the frontal, maxillary, and nasal bone the bright thin mucosa was delineated against signal free bone. This was best seen in the T2w sequences and the proton density weighed images. The delineation against the dental alveola and spiral lamellae of the dorsal and ventral concha was seldom possible.

The intermaxillary septum that separates the rostral maxillary sinus from the caudal maxillary sinus are visible through the mucosa covering it from rostral and caudal. The bone forming the septa was not clearly delineated. In the dorsally oriented studies the mucosa from both sides of the intermaxillary septa could be seen as a transverse, slightly blurred line that was visible over the whole ventrodorsal extent of the maxillary sinuses. In the transversely oriented studies the intermaxillary septum could be seen in all horses as blurred lines within the maxillary sinuses. These lines started dorsally at the level of the infraorbital canal. The further rostral the transverse image was located the more ventral the blurred lines were visible. Cranial the blurred lines connected with the floor of the rostral maxillary sinuses.

The conchal septa were also visible as transverse bright lines in the dorsally oriented images. The intermaxillary septa and the conchal septa were clearly visible in all dorsally oriented sequences. In cases where a slice of the transversely oriented studies depicted the conchal septa, they were visible as blurred, interrupted bright lines that filled the respective concha. The appearance resembled that of the intermaxillary septa. In three horses small amounts of hyperintense fluid were found in the paranasal sinuses. In one horse it was found in the right frontal sinus, in the other two it was found in the right ventral conchal sinus. There was no distinguished demarcation between the fluid and the mucosa of the paranasal sinuses since they showed the same signal intensity in all performed MR sequences. The fluid was still recognized as such due to the presence of a horizontal air-fluid level (Fig. 7). In one horse bright swollen mucosa was visible on the floor of the right ventral conchal sinus over an extent of $1.5 \mathrm{~cm}$ from rostral to caudal.

\section{The nasomaxillary aperture}

The middle nasal meatus was well delineated and the course of the nasomaxillary aperture orienting from the middle nasal meatus proceeding laterally in a dorsal convex shape was also clearly visible in all transverse sequences. The dorsal limitation could be assigned to the spiral lamella of the dorsal concha and the ventral limitation could be assigned to the spiral lamella of the ventral concha. The lumen of the nasomaxillary aperture that leads into the rostral and caudal maxillary sinus was not visible in the transverse oriented sequences. The mucosa lining the ventral and dorsal walls of the nasomaxillary aperture occurred as bright rippled lines that merged at some points so that the canal between them was blurred (Fig. 8). These circumstances were present in all
Fig. 8 T2w MR image; middle nasal meatus (chevrons) and nasomaxillary aperture (arrow heads) at the level of the M2.

T2-gewichtetes MRT Schnittbild, mittlerer Nasengang (Sparren) und Apertura nasomaxillaris (Pfeilspitzen) auf der Höhe des M2

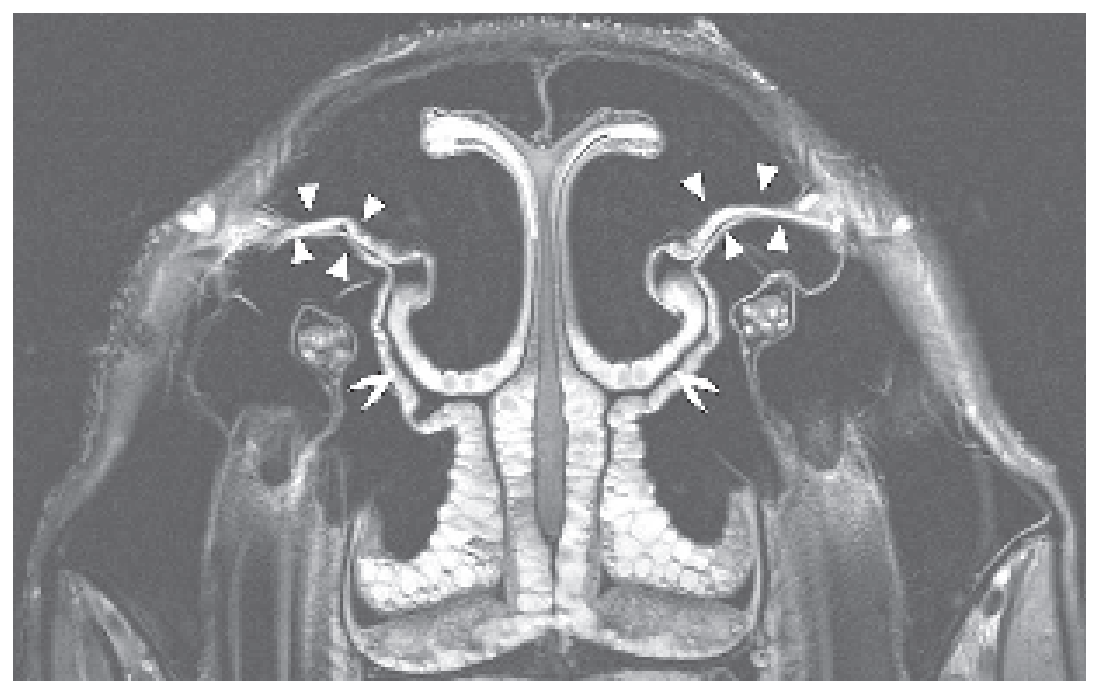


transverse sequences. In the dorsally oriented sequences the nasomaxillary aperture could not be identified in any slice.

\section{The infraorbital canal and infraorbital nerve}

In the transversally oriented sequences the bone of the infraorbital canal could be seen as a signal free ring within the signal free maxillary sinuses. It becomes visible through the bright mucosa covering the bony surface facing the paranasal sinuses which is part of the inner mucosal lining of the maxillary sinuses. The shape of the infraorbital canal differed from rostral to caudal and interindividually. Where the infraorbital canal was not in contact to the alveoli of the maxillary cheek teeth, it was held in position by a thin vertical signal free bone plate. Here the infraorbital canals of both sides had an oval shape that resembled that of an air filled balloon in ten horses. In two horses the shapes of both infraorbital canals were roughly polygonal. In a 20 year old warmblood mare the shape of the infraorbital canal of each side differed. One side showed the described balloon like shape while the other was transverse oval. In seven horses the infraorbital canal was in direct contact to the alveoli of a differing number of maxillary cheek teeth. When in contact with the alveola the shape of the infraorbital canal was irregular and aligned with the alveola (Fig. 9).

The position of the infraorbital canal in relation to the surrounding anatomical structures showed age related differences. Dependent on the age of the horse the infraorbital canal

Fig. 9 PDw MR image, infraorbital canal with thin bright mucosal lining and signal free cortical bone (arrow heads) in direct contact to the palatal alveola of the M2 in a four year old mare; infraorbital nerve (1), infraorbital artery and / or vein (2).

Protonengewichtetes MRT Schnittbild, Canalis infraorbitalis mit dünner, signalreicher Schleimhaut und signallosem kompakten Knochen (Pfeilspitzen) im direkten Kontakt zum palatinalen Zahnfach des M2 bei einer 4-jährigen Stute; Nervus infraorbitalis (1), Arteria oder Vena infraorbitalis (2)

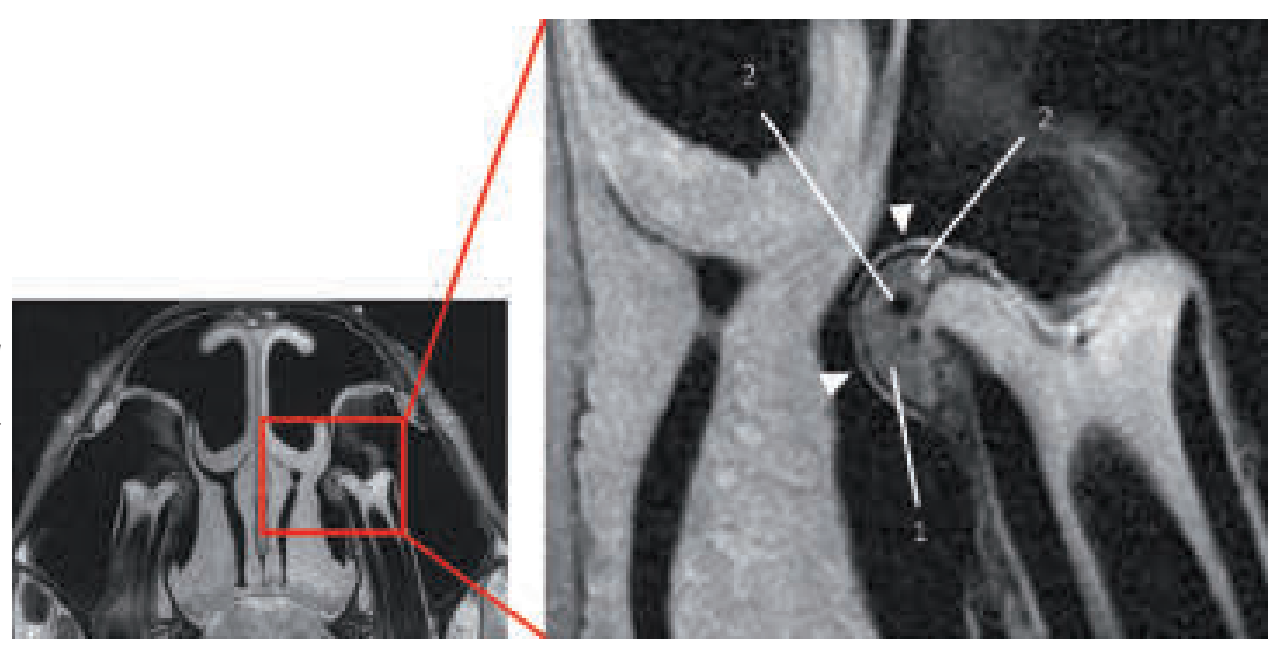

Fig. 10 T2w MR image, infraorbital canal (arrow head) at the level of the $\mathrm{Ml}$; thin hyperintense line (1) descending in the direction of the dental alveola of the M1 (2).

T2-gewichtetes MRT Schnittbild, Canalis infraorbitalis (Pfeilspitzen) auf der Höhe des MI, dünne hyperintense Linie (1), die in Richtung des Zahnfachs des M1 (2) zieht

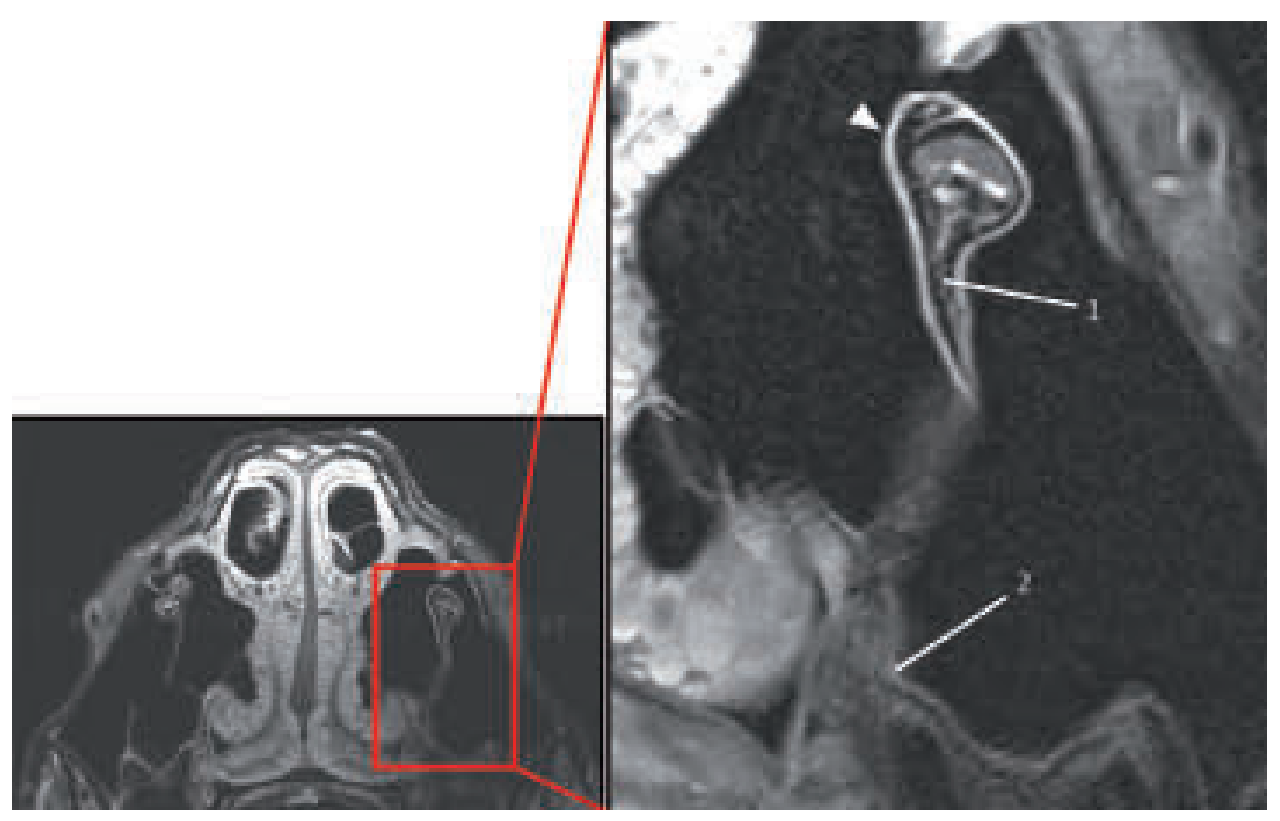

Table 2 Contact of the infraorbital canal to dental alveola of maxillary cheek teeth / Kontakt von Infraorbitalkanal und maxillaren Backenzahnalveolen

\begin{tabular}{lc}
\hline Age $(\mathrm{n})$ & In contact to dental alveola of maxillary cheek teeth \\
\hline 5 to 7 years $(5)$ & $\mathrm{P} 4, \mathrm{M} 2, \mathrm{M} 3$ \\
4 years $(1)$ & $\mathrm{P} 4, \mathrm{M} 1, \mathrm{M} 2, \mathrm{M} 3$ \\
7 years $(1)$ & $M 2, M 3$ \\
14 to 20 years $(6)$ & none \\
\hline
\end{tabular}


Fig. 11 T2w MR images, a: nasal septum (arrow heads) at the level of the M2 with homogenous appearance; $b$ : nasal septum (arrow heads) at the level of the M3 with divided appearance, brigh dorsal part (1), hypointense ventral part (2).

T2-gewichtetes MRT Schnittbild, a: Nasenseptum (Pfeilspitzen) auf Höhe des M2 mit einem homogenen Erscheinungsbild, $b$ : Nasenseptum (Pfeilspitzen) auf Höhe des M3 mit einem zweigeteilten Erscheinungsbild, signalreicher dorsaler Anteil (1), hypointenser ventraler Anteil (2)
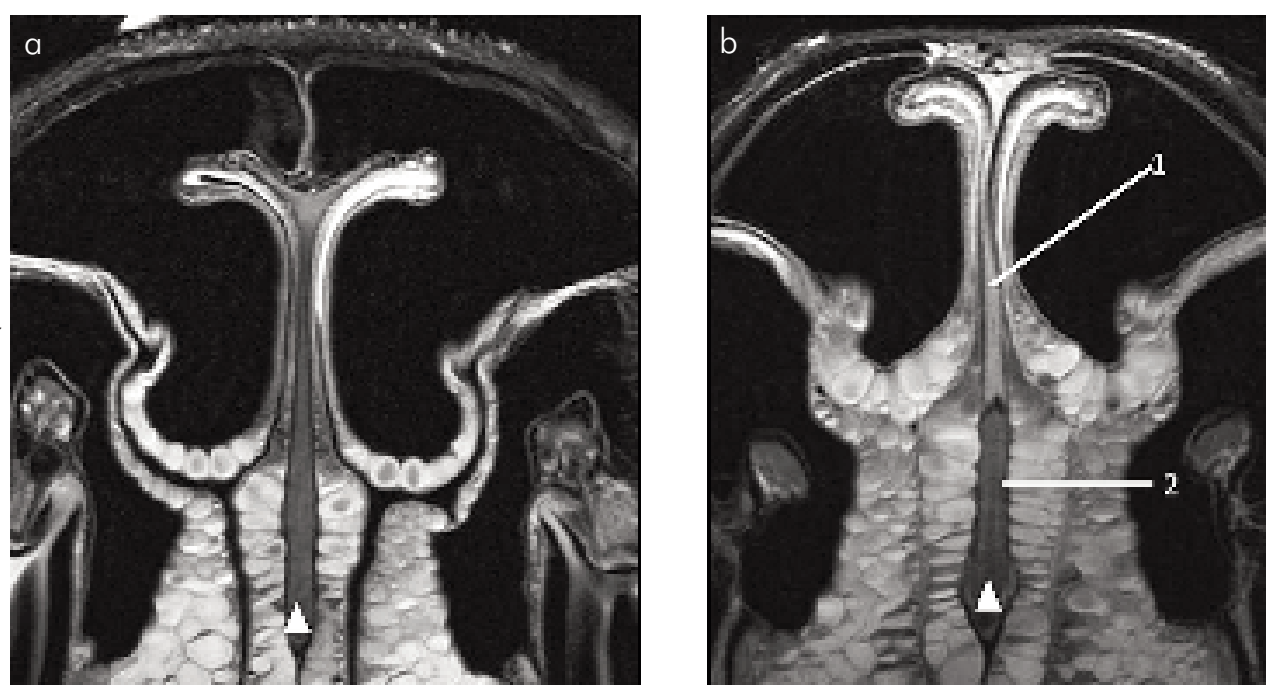

was in close contact to the dental alveola of a different number of maxillary cheek teeth (Tab. 2). In two horses the infraorbital canals of the right and left side were not on the same dorsoventral level. The levels differed 4 to $6 \mathrm{~mm}$. In the parts where the infraorbital canal was not in contact with the alveoli of the maxillary cheek teeth a thin line with high to moderate signal intensity was visible in some slices that originated from the inside of the infraorbital canal, passed through the thin lamella holding the canal in place and ended at one of the apices of the dental alveolus (Fig. 10).

The soft tissue enclosed in the canal could be seen as inhomogeneous composition of different structures with high to moderate signal intensity. Most of the canal's lumen was taken up by the infraorbital nerve which could be seen as a tissue with moderate signal intensity. The transverse shape of the nerve was adjusted to the form of the infraorbital canal. Adjacent to the infraorbital nerve blood vessels were apparent in most of the images that were either visible as a signal free or bright spot (Fig. 9). At the infraorbital foramen where the bony infraorbital canal ends, the infraorbital nerve flattened against the maxillary bone and stretched further dorsally and ventrally. The blood vessels could not be traced from that point rostrally. In some slices the structure of the infraorbital nerve and the form of the infraorbital canal seemed contorted and made an accurate distinction of the infraorbital nerve and blood vessels impossible. The transverse oriented sequences using a higher resolution, i.e. T2w sequences and PDw sequences, were superior in depicting the infraorbital canal and the infraorbital nerve within the canal. The T1w sequences did not delineate the soft tissue inside the infraorbital canal against the bone.

\section{The nasal septum}

The nasal septum showed different appearances in the thirteen horses. In six horses (age 4 to 7 years) the septum appeared homogenous with moderate signal intensity over the whole depicted extend from caudal to rostral and dorsal to ventral (Fig. 11a). In three horses (age 14 to 20 years) the septum had two different properties. The dorsal part had high signal intensity while the ventral part had moderate signal intensity (Fig. 11 b). Both parts were separated by a thin signal free line. Both parts, the dorsal and ventral one were framed by a thin signal free line. In four horses (age 7 to 19 years) those two different appearances (homogenous and divided) were both present. In those horses the rostral part of the septum was homogenous with moderate signal intensity while the caudal part of the septum showed the described division between dorsal and ventral. In three horses this division was from a level of the second molar cheek tooth caudally and in one horse from the third molar tooth caudally. The sequences using high resolutions were more accurate in depicting the borderline between the two mentioned qualities. In nine horses (age 5 to 20 years) either a slight deviation to the right or left, a sigmoid deviation from dorsal to ventral, or a combination of both types was present. In four horses (age 4 to 7 years) no sort of deviation of the nasal septum could be seen. The differences in the appearance of the nasal septum could be seen in all of the viewed transverse oriented sequences.

\section{The venous plexus}

Next to the description a total of 48 slices of the transversely oriented T2w sequences of twelve horses were chosen for measurement of the venous plexus and mucosa lining the walls of the nasal cavity. The images of one horse had to be excluded from measurements because of movement artefacts which made accurate measurements impossible. In all thirteen horses the venous plexus underlying the mucosa of the nasal meatus occupied most of the available space so that all four nasal meatus were occluded in four horses (Fig. 12). In nine horses a narrow slit like lumen of 1 to $4 \mathrm{~mm}$ remained. There were no differences in the amount of space left in a right-left comparison. In transverse images the plexus were composed of bundled venules that were round or oval shaped. The single venules were clearly delineated in the transverse oriented T2W images and the PDw images. In T2w images part of the venules appeared homogenous with high signal intensity while others appeared divided into two halves. At this the ventral half had a high signal intensity while the dorsal half had a moderate to low signal intensity. This could also be found in the PDw images. As a third appearance the venules were visible with a dark round centre of low signal intensity that was surrounded by bright area that was filling the rest of the venule. This appearance could only be found in the T2w images and not in PDW images. All venules regardless of their appearance were delineated from each other by a dark, thin line. 
Fig. 12 T2w MR image, nasal cavities at the level of the M3; all four nasal meatus are completely congested (arrow heads).

T2-gewichtetes MRT Schnittbild, Nasenhöhlen auf Höhe des M3, alle vier Nasengänge sind vollständig verlegt (Pfeilspitzen)

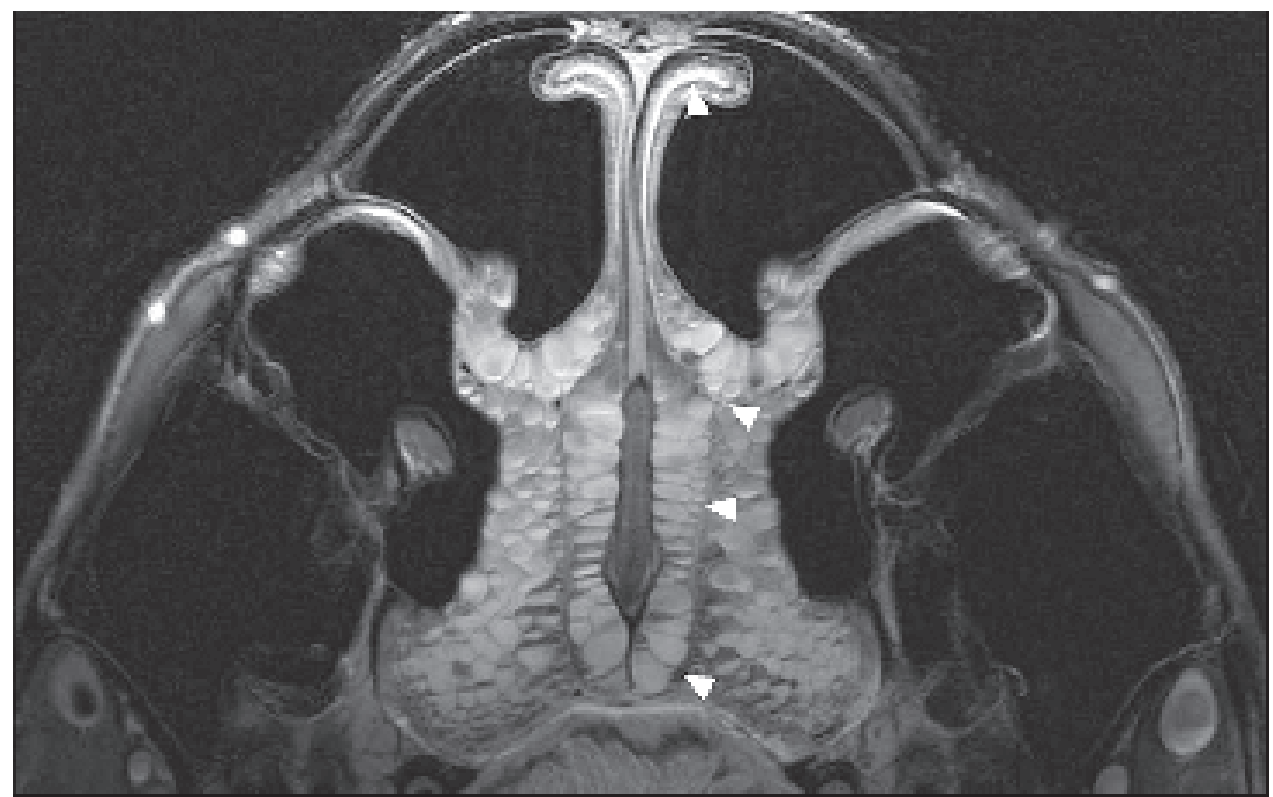

Fig. 13 T2w MR image, dorsal view of the venous plexus of the nasal mucosa lining the spiral lamella of the ventral conchal sinus at the level of the facial crest, single venules running from rostral to caudal (arrow heads).

T2-gewichtetes MRT Schnittbild, dorsale Ansicht der Venenplexus der Nasenschleimhaut, die die Spirallamelle der ventralen Nasenmuschel auf Höhe der Crista facialis bedecken; einzelne Venulen, die von rostral nach kaudal verlaufen (Pfeilspitzen).

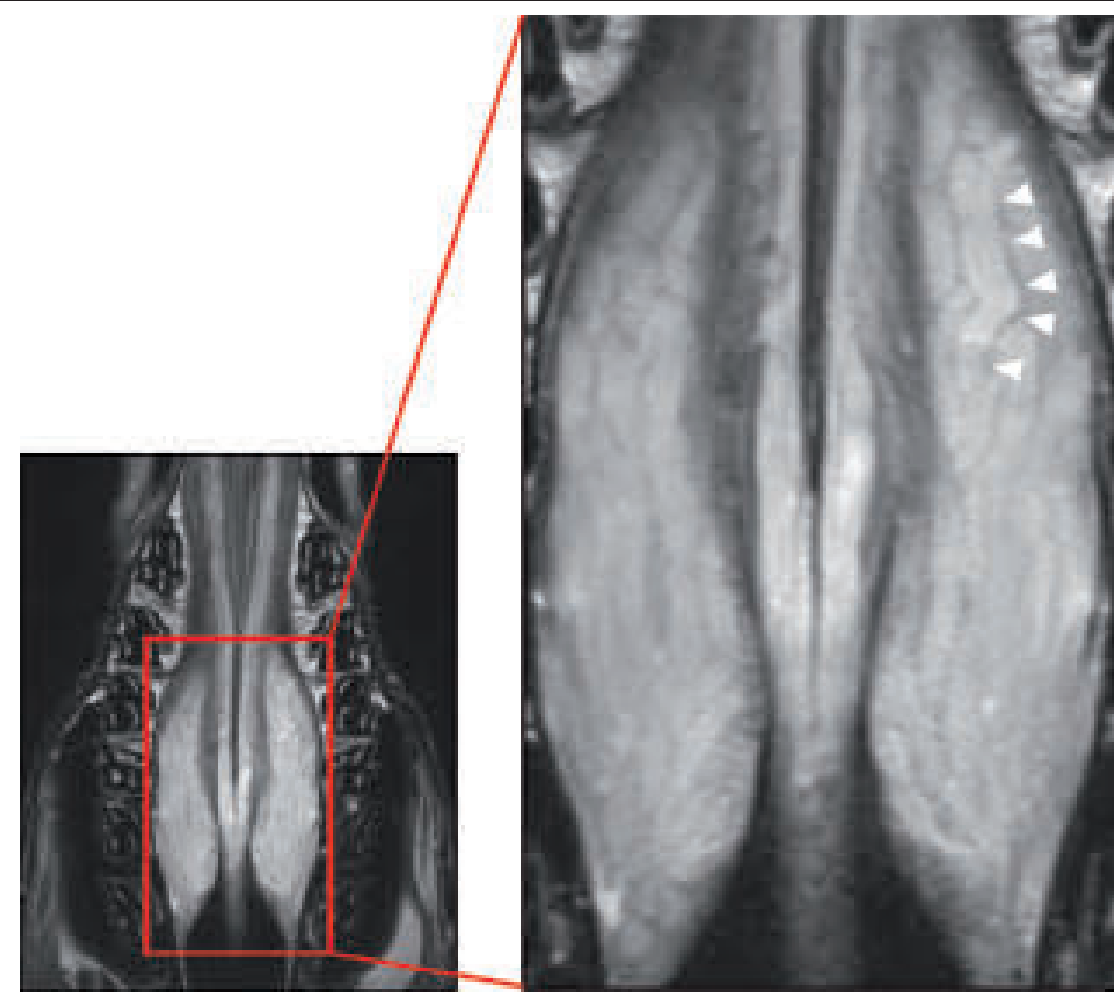

These different appearances described in T2w and PDw images could not be found in the T1 $\mathrm{w}$ images in which the plexus appeared as a homogenous isointense area and the single venules could only be seen as separate structures in some slices. When they were visible as single structures, they had the same shape as described in T2w images and they appeared homogenous with a moderate to high signal intensity. In the dorsally oriented images the venous plexus could be seen as areas with high signal intensity and in some slices the venules were visualized in their caudal to rostral extent as curved strands that were delineated against each other by thin dark lines (Fig. 13). In combination with the transverse images one can conclude that the venules proceed as tubes from rostral to caudal.

In the transverse images the most caudally located venous plexus were visible in a plane directly rostral to the ethmoid bone. They formed a U-shape around the vomer and nasal septum. Immediately rostral to that location the most caudally located venous plexus originating from the spiral lamella of the ventral concha projected into the lumen of the ventral nasal meatus. With the start of the spiral lamella of the dorsal concha the venous plexus lining the spiral lamella were also visible from that point rostrally.

Further rostrally the plexus lining the septum and vomer lost their U-shape at the point where the choanae end and the vomer connects with the palatine suture. Here the plexus still lined the septum on each side but ventrally they continued in a lateral direction and underlay the mucosa of the ventral nasal meatus. The median for the measured thickness of the nasal mucosa and the plexus lining the nasal septum (Fig. 1 to 4 , red lines) was $8.38 \mathrm{~mm}$ with a range from $2.92 \mathrm{~mm}$ to $16.46 \mathrm{~mm}$ (Tab. 3). Only one layer of venules was forming the venous plexus under the mucosa of the floor of the ventral nasal mea- 
tus. The mucosa of the floor of the ventral nasal meatus appeared thick due to a layer of tissue that was isointense in T2w sequences and hypointense in the T1w sequence.

Over the rostral to caudal length of the visualized area the dorsal part of the nasal septum was not lined by venous plexus. Beginning at the level of the middle nasal meatus the plexus started to fade dorsally till only the mucosa was left. Further rostral beginning at the level of the infraorbital foramen the ventral parts of the venous plexus that were lining the septum were also fading so that only the middle part of the septum was still lined by venous plexus. At the same level the above described tissue lining the floor of the nasal cavity was not present anymore and only a triangular area of plexus between the floor and the septum remained.

The plexus lining the ventral concha were visible as far rostrally as the field of view allowed. The field of view ended at a level directly rostral to the infraorbital foramen. In some places there were up to five venules stacked on top another and in other locations only one layer of venules existed. The plexus' thickness varied from caudal to rostral without apparent order. The median for the measured thickness of the nasal mucosa and plexus at the apex of the spiral lamella of the ventral concha (Fig. 2 to 4, green lines) was $14.41 \mathrm{~mm}$ with a range from $7.20 \mathrm{~mm}$ to $25.50 \mathrm{~mm}$ (Tab. 3). The plexus lining the dorsal concha were not as thick as the ones of the ventral concha and only consisted of one layer of venules which varied in size. The part of the middle nasal meatus that leads into the nasomaxillary aperture was also lined by a single layer of venules, that gradually thinned out in proximity to the nasomaxillary aperture until it was not present any more and only mucosa remained. For the median for the measured thickness of the venous plexus and mucosa of the middle nasal meatus (Fig. 2, dl, dm, vl, vm) see Table 3.

\section{The maxillary cheek teeth}

In all horses six permanent cheek teeth were present and displayed in every sequence and orientation. The length of the teeth differed in relation to the individual horse as physiological in age related wear of the teeth. The cheek teeth's pulp was visible from apical to occlusal in all horses with a high signal intensity in T2w and PDw images. In T1w images it showed high to moderate signal intensity. The full extent of the pulp horns was best seen in T2w images with dorsal orientation. The dentin, enamel and cement of the cheek teeth were dark and without signal and therefore not distinguishable from each other.

The reserve crown of the teeth was delineated against the periodontal ligament which is a thin, bright line surrounding the tooth. In some cases a thin, signal free line surrounded the periodontal ligament which is compact bone of the alveola (Lamina dura). Surrounding the roots of the maxillary

Fig. 14 T2w MR image, bright dental sac (arrow heads) surrounding the reserve crown of the right maxillary P4 in a four year old mare.

T2-gewichtetes MRT Schnittbild, signalreiches Zahnsäckchen (Pfeilspitzen), das die Reservekrone des P4 umgibt, bei einer 4-jährigen Stute.

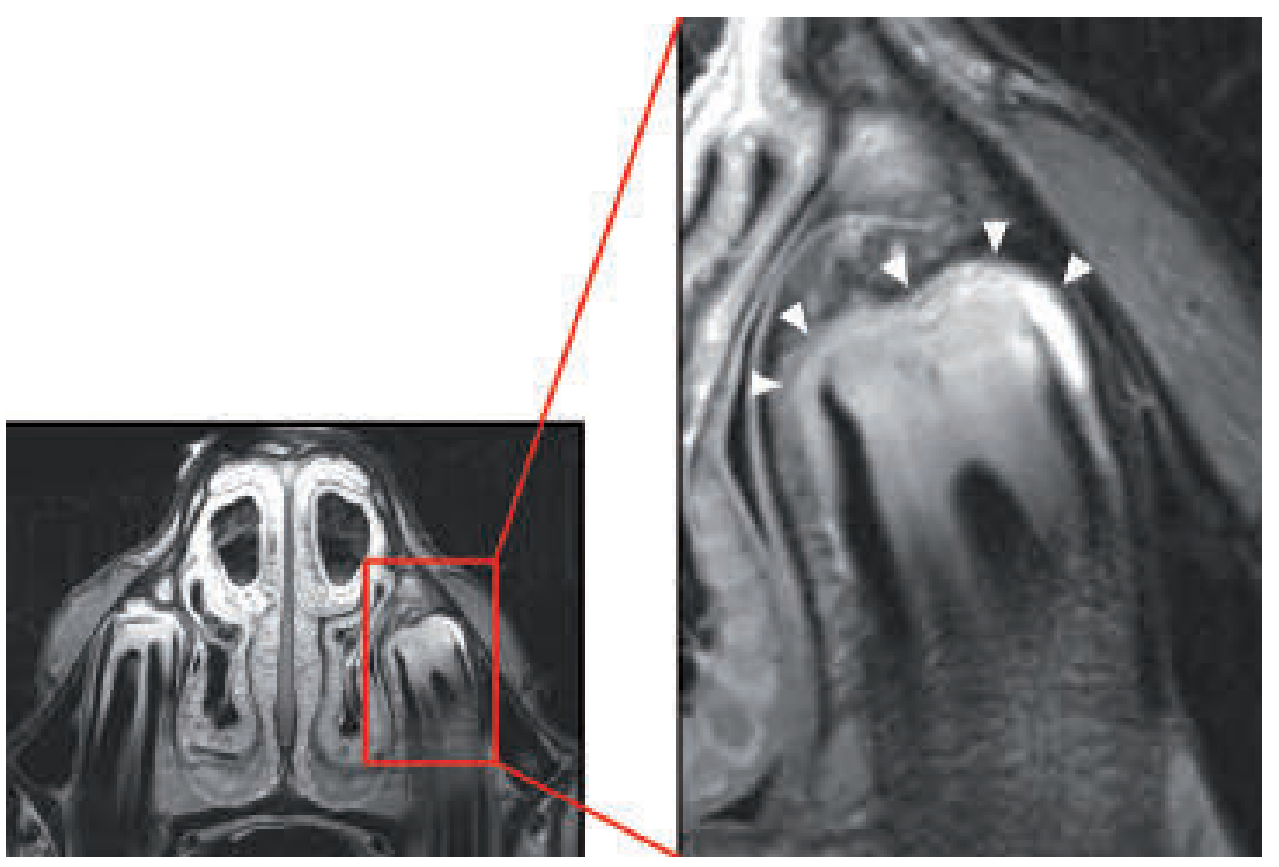

Table 3 Median (range) of the measured thickness of the nasal mucosa and venous plexus (Fig. 1 to 4) / Durchschnittliche gemessene Dicke von nasaler Mukosa und Venenplexus

\begin{tabular}{lll}
\hline measured point & median (mm) & $\min -\max (\mathrm{mm})$ \\
\hline nasal septum (Fig. 2-5, red lines) & 8,38 & $2,92-16,46$ \\
vental concha (Fig. 3-5, green lines) & 14,41 & $7,20-25,50$ \\
middle nasal meatus dorsal lateral (Fig 3, dl) & 3,55 & $2,14-7,41$ \\
middle nasal meatus dorsal medial (Fig 3, dm) & 7,48 & $4,56-9,77$ \\
middle nasal meatus ventral lateral (Fig. 3, vl) & 1,91 & $1,21-3,71$ \\
middle nasal meatus ventral medial (Fig. 3, vm) & 8,62 & $5,59-14,23$ \\
\hline
\end{tabular}


cheek teeth was either bright medullary bone or dark compact bone with a thin bright mucosa depending on the position of the maxillary cheek tooth. The dental sac surrounding the reserve crown of growing teeth could be seen in three horses (age 4 to 5 years). Here the reserve crown of the sixth maxillary cheek teeth in all 3 horses was covered with a signal intense zone that was delineated against the alveolar bone. This was also present in the third maxillary cheek teeth in one of the five year old horses and in the second and third maxillary cheek teeth of the four year old horse (Fig. 14).

\section{Discussion}

In the present study tomographic images of the nasal cavities and the paranasal sinuses of 13 live and healthy horses were acquired using 3 Tesla MRI. The imaging process was possible in all 13 horses. This successful outcome cannot be generalized for horses of all breeds and sizes. The design of the Philips AchievaTM 3.0 T X-Series ${ }^{\circledR}$ (Philips Medical Systems, Best, The Netherlands) holds problems for some horses. The magnet has a length of $167 \mathrm{~cm}$ and structures of interest have to be placed in the centre of the magnet. The patient aperture of the magnet has a diameter of $60 \mathrm{~cm}$. Both of these features combined imply that the head of horses with a short and / or thick neck cannot be positioned in the centre of the bore.

The quality of the images varied from horse to horse even with a standardized set of sequences. These variations appeared due to variables present in this MRI examination. The coils used in this study are flexible surface coils that were placed around the structures of interest. They only allow for a field of view of about $30 \mathrm{~cm}$ in length. Slight mispositioning can lead to a loss of signal on the edges of the field of view. In this study the zygomatic process of the temporal bone was used as a prominent anatomical landmark. The caudal edge of the surface coils (Philips SENSETM Flex $M^{\circledR}$ and Philips SENSETM Flex L ${ }^{\circledR}$; Philips Medical Systems, Best, The Netherlands) was always positioned at the level of the zygomatic process. The restricted size of the field of view will also lead to better and more complete studies of the nasal and paranasal sinuses in horses with a smaller head. The differences in the field of view did not lead to differences in voxel size since the image matrix and slice thickness were the same in all the examined horses.

The aim of the study was to depict the equine paranasal sinuses and the nasal cavities. The limited field of view did not allow for the whole head to be scanned. The caudal part of the conchofrontal and the sphenopalatine sinuses were not depicted as well as rostral parts of the rostral nasal cavities. This inherent limitation of MRI needs to be considered for the positioning of a potential patient inside the magnetic field and the positioning of the receiver coils around the area of interest.

MRI sequences are susceptible to artefacts caused by movements of the patient (Weishaupt et al. 2009). Motion artefacts can be caused by physiologically appearing motions like breathing and heartbeat (Murray and Dyson 2007). In the present study movement artefacts occurred in one horse. They were explicable due to a tachycardia that was caused by a bolus injection of $0.01 \mathrm{mg} / \mathrm{kg}$ body weight atropine after the horse showed a severe bradycardia under general anaesthesia.

The nasal cavities were well depicted in the MR images this is due to their high amount of soft tissue in form of the venous plexus of the nasal mucosa that lead to a high contrast in the images. The paranasal sinuses are described as air filled cavities lined by mucosa (Waib/2004, Salomon 2008). Since air lacks protons that can emit any signal in MRI they appear black or signal free. Cortical bone is also dark in MR images and only the thin mucosal lining can be used to outline the borders of the paranasal sinuses where air and cortical bone lie right next to each other (Weishaupt et al. 2009). In all acquired MR images the paranasal sinuses were well delineated by bright mucosal lining. The bright mucosal lining allowed for an adequate distinction between the signal free, air filled sinus cavity and signal free cortical bone. In presence of inflammation of the depicted mucosa a thickening of the mucosal lining will be present (Tremaine and Dixon 2001, Bienert 2002).

In three horses fluid was present in the paranasal sinuses. The fluid was not distinguishable from the thin mucosal lining of the paranasal sinuses. If fluid is present in the paranasal sinuses in cases of clinical diagnostics it might be difficult or even impossible to establish if swollen or hypertrophic mucosa is present. In one horse that showed fluid inside the right ventral conchal sinus, mucosal lining that was in contact with the dental alveola of the right maxillary MI was thicker than the mucosa on the contralateral side. This can be interpreted as a localized swelling of the mucosal lining as a result of inflammation. The fluid inside the ventral conchal sinus might be exudate stemming from the inflamed mucosa comparable to a case presented in a study by Gerlach et al. (2011).

Arencibia et al. (2000) and Gerlach et al. (2009) used MRI to develop an overview over the appearance of anatomical structures in the equine head. Gerlach et al. (2009) used three live horses and three cadaver specimen in which the head was disembodied for the imaging process. Arencibia et al. (2000) used two cadaver heads. Junker et al. (2002) scanned six cadaver heads to use as a comparison to different pathological cases. In the present study all horses were alive during the imaging process. The use of disembodied heads eliminates the aforementioned problems of positioning the area of interest inside the magnet since the neck and body do not interfere with the magnets casing, but certain differences between the in vivo imaging and ex vivo imaging are present. MRI displays the condition of tissues in terms of the distribution of protons in those tissues. In ex vivo studies the lack of blood flow to the different anatomical structures in the depicted area will lead to an alteration in the afore-mentioned distribution of protons. Additionally the appearance of blood vessels will change through the lack of blood pressure and the stagnancy of blood. In in vivo imaging this will lead to the outflow effect in blood vessels that lets the vessels appear with low signal intensity or even signal free (Weishaupt et al. 2009). Furthermore it leads to a different appearance of the erectile tissue of the nasal mucosa in form of a decongestion. The venous plexus of the nasal mucosa appear thinner as in the present study and therefore the nasal meatus will appear with a larger lumen (Arencibia et al. 2000, Gerlach et al. 2009). 
Arencibia et al. (2000) and Gerlach et al. (2009) used magnets with a magnetic field strength of 1.5 Tesla while Junker et al. (2002) used one with a field strength of 0.2 Tesla. A stronger magnet with a field strength of 3 Tesla has advantages and disadvantages over magnets with weaker magnetic fields. The stronger magnetic field allows for a higher signal to noise ratio which allows for a higher resolution in images. Especially in T2w sequences this can be used to shorten the time needed for picture acquisition with equal quality compared to magnets with lower field strength which is desirable especially in equine patients since the time in general anesthesia can be reduced (Merkle and Dale 2006, Chang et al. 2008, Weishaupt et al. 2009). In T1w spin echo sequences the time for acquisition is prolonged in 3 Tesla MRI since T1 relaxation times are longer (Merkle and Dale 2006, Chang et al. 2008, Weishaupt et al. 2009).

Other disadvantages of the 3 Tesla MRI involve pronounced susceptibility artefacts and chemical shift artefacts as well as standing wave artefacts (Merkle and Dale 2006, Chang et al. 2008). The reduction in time that could be achieved with a 3 Tesla magnet is limited since the energy of the radio frequency waves needed for the examination have a higher energy and lead to faster heating of examined tissue. The energy in a 3 Tesla magnet is quadrupled in comparison to a 1.5 Tesla magnet (Chang et al. 2008).

In the present study the higher signal to noise ratio could be used to acquire T2w and PDw images with a very high resolution which allowed for a detailed depiction of delicate structures like the ethmoid bone, the infraorbital nerve, the periodontal ligament and the venules of the venous plexus of the nasal mucosa. In previous MR studies T1 w images were used for anatomical visualization of different structures (Arencibia et al. 2000, Busoni et al. 2005, Mair et al. 2005). In the present study the visualization of anatomical structures was superior in the T2w images compared to the T1w images. This cannot be seen as a general circumstance in 3 Tesla MRI since $\mathrm{T} 1 \mathrm{w}$ sequences might show the same detail if more time for image acquisition was spent.

In some images the well delineated lines of some structures showed a slightly blurred appearance and the structures appeared contorted. The same effect could be seen in the intermaxillary septum in the transverse oriented images and the nasomaxillary aperture. These irregularities occurred in all horses and were not attributable to any pathology. There are two reasons for the irregularities. The first one is the orientation of the tomographic imaging. In this study the hard palate and its rugae palatinae and the nasal septum were chosen as anatomical landmarks. The anatomical structures depicted in this study show different positions and orientations in relation to the chosen landmarks. This fact leads to the inevitability that some structures are depicted with an oblique plane. In those cases it is important to perform studies in more than one orientation so that pathological changes in the structures appearance can be ruled out. Every additional acquired study will add time to the entire examination. The second reason for the blurred appearance of some delicate structures is the partial volume effect that occurs when structures with different properties are positioned in one voxel and their signals are averaged during picture acquisition (Weishaupt et al. 2009). This effect could be avoided using a lower slice thickness which would lead to a longer acquisition time or a lower signal to noise ratio and lower quality of the acquired images. Gerlach et al. (2011) described the appearance of the infraorbital nerve and the joining blood vessels as shown in this study. The high resolution of the T2w and PDw images allowed for the description of a line with moderate signal intensity that can be seen in some slices originating from the infraorbital canal and ending at the apices of the maxillary cheek teeth. These thin lines represent rami from the infraorbital nerve or the infraorbital vein or artery sub serving the maxillary cheek teeth (Böhme 2004, Waibl et al. 2005).

In literature the venous plexus of the nasal mucosa can be composed of up to five layers of venules (Ackerknecht 1943). The venules' walls contain sphincter muscles which gives them the function of an erectile tissue (Liebich 2004, Salomon 2008). The venules of the nasal mucosa could be seen in all 13 horses. The venules appeared as bundled and not organized in distinct layers. Up to five venules overlay each other in this bundled fashion from lateral to medial in accordance to Ackerknecht (1943). In all of the 13 horses examined in this study the venous plexus of the nasal mucosa were congested and the nasal passages were reduced to a minimum.

In the human physiology it is described that a rise in venous pressure of one of the internal jugular veins is followed by a congestion of the ipsilateral venous plexus of the nasal mucosa. A rise in the venous pressure can occur due to pressure that is applied from the outside or the positioning of the head in a lower position in relation to the heart. This is the case in recumbent positions. In a person lying on its side the venous plexus of the bottom side congest while the venous plexus of the other side decongest (Babatola 1998). Assuming that similar mechanisms apply for the horse it is probable that the positioning of the 13 horses in a dorsal recumbency with a stretched head to neck position might have led to a rise in venous pressure in both jugular veins at the same time which in turn entailed a congestion of the venous plexus of both nasal cavities.

Due to study design the first images were acquired after a period of about $20 \mathrm{~min}$ under general anaesthesia and in dorsal recumbency. At this point the venous plexus of the nasal mucosa already appeared as congested as described above and appearance did not change over time. Through the present results it is not possible to say how fast the congestion of the venous plexus proceeded. In in vivo MRI blood vessels appear dark or without signal due to the out flow effect (Weishaupt et al. 2009). The venous plexus in all 13 horses appeared mainly bright with a high signal intensity. It can be concluded that the blood in those venules is static either due to a constriction of the venules sphincter muscles or a hemodynamic stasis. In that case the blood gives signal (Weishaupt et al. 2009). The different described appearances must not be interpreted as pathologies.

The orientation of the slices could influence the measured thickness of the venous plexus since an oblique angle could let the venous plexus appear thicker than they actually are. In our study this was avoided by adjusting the slice-orientation using the hard and soft palate and the nasal septum which the plexus follow in a parallel manner. 
Ackerknecht (1943) states that the nasal mucosa with its venous plexus is $5 \mathrm{~mm}$ thick at the ventral base of the nasal septum. The author does not write how and at what point in vivo, ex vivo - the thickness was measured. In this study the nasal mucosa with the venous plexus lining the nasal septum was measured with a maximum thickness of $16.46 \mathrm{~mm}$ and a median of $8.38 \mathrm{~mm}$ at the level of the nasal meatus for all 13 horses. Ackerknecht (1943) does not state any other values for comparison.

The nasal septum appeared divided in seven of the 13 horses. Veterinary anatomical literature describes the nasal septum as composed of hyaline cartilage (König and Liebich 2005, Salomon 2008). This could be seen in the moderate signal intensity of the main part of the septum. It is also described that parts of the hyaline cartilage start to ossify with age (Sisson 1914, König and Liebich 2005). The bright dorsal part of the septum that was visible in horses in which a division was present might be ossified cartilage that was composed of bone marrow with surrounding compact bone and is therefore to be seen as a physiological state. It is probable that the described division appears in horses of higher age. In four horses (age 7 to 19 years) the rostral part of the nasal septum showed no ossification while the caudal part showed the described division. This might suggest that the ossification of the septum proceeds from caudal to rostral since three horses (age 14 to 20 years) showed a complete division over the whole field of view. The age of the examined horses suggests an age related difference of the appearance. In older horses the division is more likely to be present. For better assessment of the age dependent variations in the appearance of the nasal septum further studies with larger populations of horses should be conducted in which the MRI findings are compared and complemented with histological examinations. All the different appearances described in this study must not be interpreted as pathologies if present in clinical cases.

The appearance of the maxillary cheek teeth corresponds with those already demonstrated by (Gerlach et al. 2011). They stated that a T2w sequence with a dorsal orientation is most useful as a survey sequence to asses for dental pathologies. In the present study this sequence also gives the best overview over the complete extent of the maxillary cheek teeth.

\section{Conclusion}

The present study displays and describes the difference of appearances of anatomical structures in high field (3 Tesla) magnetic resonance imaging of the equine nasal cavities paranasal sinuses and their communication ways. The results of this study can be used by clinicians working with high field MRI for the interpretation of images of this particular region and for anatomical orientation. Additionally clinicians can use the results of the present study to differentiate between physiological, individual, anatomical variations and pathological findings as well as age related differences in appearance.

In the living horse that is positioned in a dorsal recumbency with a stretched head and neck position a congestion of the venous plexus of the nasal mucosa is always present. The results further the knowledge of anatomical and physiological states of the nasal cavities in equine veterinary medicine but they also demonstrate that further investigations with higher numbers of horses are needed to fully comprehend the observed anatomical variations.

\section{References}

Ackerknecht E. (1943) Die Atmungsorgane des Pferdes. In: O. Zietzschmann, E. Ackerknecht and H. Grau (eds) Ellenberger / Baum: Handbuch der vergleichenden Anatomie der Haustiere. Berlin: Springer, 18, 464-498

Arencibia A., Vazquez J. M., Jaber R., Gil F., Ramirez J. A., Rivero M., Gonzalez N., Wisner E. R. (2000) Magnetic resonance imaging and cross sectional anatomy of the normal equine sinuses and nasal passages. Vet. Radiol. Ultrasound 41, 313-319

Babatola F. D. (1998) Reciprocal changes in nasal resistance in response to changes in posture. Rhinology 36, 69-72

Bienert A. (2002) Digitalradiographische, computertomographische und mikrobiologische Untersuchungen bei Backenzahnerkrankungen des Pferdes. Diss.Med. Vet. Hannover

Böhme G. (2004) Nervensystem. In: R. Nickel, A. Schummer and E. Seiferle (eds) Lehrbuch der Anatomie der Haustiere. Stuttgart: Parey Verlag, 4, 2-385

Brinkschulte M. (2012) Morphologische Untersuchung der Apertura nasomaxillaris des Pferdes sowie deren Verzweigung in die Nasennebenhöhlen unter der Anwendung dreidimensionaler Rekonstruktion computertomographischer Schnittbildserien. Diss. Med. Vet. Hannover

Busoni V., Heimann M., Trenteseaux J., Snaps F., Dondelinger R. F. (2005) Magnetic resonance imaging findings in the equine deep digital flexor tendon and distal sesamoid bone in advanced navicular disease - an ex vivo study. Vet. Radiol. Ultrasound 46, 279 286

Cavalleri J. M., Metzger J., Hellige M., Lampe V., Stuckenschneider K., Tipold A., Beineke A., Becker K., Distl O., Feige K. (2013) Morphometric magnetic resonance imaging and genetic testing in cerebellar abiotrophy in Arabian horses. BMC Vet. Res. 9, 105

Chang K. J., Kamel I. R., Macura K. J., Bluemke D. A. (2008) 3.0-T MR imaging of the abdomen: comparison with 1.5 T. Radiographics 28, 1983-1998

Garrett K. S., Woodie J. B., Cook J. L., Williams N. M. (2010) Imaging diagnosis - nasal septal and laryngeal cyst-like malformationsin a Thoroughbred weanling colt diagnosed using ultrasonography and magnetic resonance imaging. Vet. Radiol. Ultrasound 51, 504-507

Gerlach K., Brehm W., Gerhards H., Ludewig E. (2011) Diagnostik von Erkrankungen der Backenzähne des Pferdes mittels Magnetresonanztomographie. Pferdeheilkunde 27, 711-718

Gerlach K., Flatz K., Brehm W., Seeger J. (2009) Klinische Anatomie des Gesichtsbereiches des Pferdes in der Magnetresonanztomographie. Pferdeheilkunde 25, 45-52

Gerlach K., Gerhards H. (2008) Magnetresonanztomographische Merkmale von Zubildungen im Brereich der Nase, Nasennebenhöhlen und der angrenzenden Knochen: retrospektive Analyse von 33 Pferden. Pferdeheilkunde 24, 565-576

Gutierrez-Crespo B., Kircher P. R., Carrera I. (2013) 3 Tesla magnetic resonance imaging of the occipitoatlantoaxial region in the normal horse. Vet. Radiol. Ultrasound online preview,

Hontoir F., Nisolle J. F., Meurisse H., Simon V., Tallier M., Vanderstricht R., Antoine N., Piret J., Clegg P., Vandeweerd J. M. (2013) A comparison of 3-T magnetic resonance imaging and computed tomography arthrography to identify structural cartilage defects of the fetlock joint in the horse. Vet. J. 199, 115-122

König H. E., Liebich H.-G. (2005) Atmungsapparat (Apparatus respiratorius). In: H. E. König and H.-G. Liebich (eds) Anatomie der Haussäugetiere, Lehrbuch und Farbatlas für Studium und Praxis. Stuttgart: Schattauer, 3, 367-388

Liebich H.-G. (2004) Atmungsapparat. In: H.-G. Liebich (eds) Funktionelle Histologie der Haussäugetiere - Lehrbuch und Farbatlas für Studium und Praxis. Stuttgart / New York: Schattaver, 4, 239-254 
Mair T., Kinns J., Jones R. D., Bolas N. (2005) Magnetic resonance imaging of the distal limb of the standing horse. Equine Vet. Educ. 17, 74-78

Merkle E. M., Dale B. M. (2006) Abdominal MRI at 3.0 T: the basics revisited. Am. J. Roentgenol. 186, 1524-1532

Murray R. C., Dyson S. (2007) Image Interpretation and Artifacts. Clini. Tech. Equine Pract. 6, 16-25

Salomon F.-V. (2008) Atmungsapparat, Apparatus respiratorius. In: F.-V. Salomon, H. Geyer and U. Gille (eds) Anatomie für die Tiermedizin. Stuttgart: Enke Verlag, 2, 324-367

Sisson S. (1914) The Respiratory System of the Horse. In: S. Sisson (eds) The Anatomy of the Domestic Animals. Philadelphia and London: W.B. Saunders Company, 2, 508-514

Deutsche Übersetzung

\section{Darstellung der Nasenhöhlen, Nasennebenhöhlen und angrenzender anatomischer Strukturen im 3 Tesla- Magnetresonanztomographen bei 13 gesunden Pferden}

\section{Einleitung}

Die Hochfeld-Magnetresonanztomographie (MRT) kommt in der Pferdemedizin immer häufiger zum Einsatz (Arencibia et al. 2000, Gerlach und Gerhards 2008, Gerlach et al. 2009, Garrett et al. 2010). Mit dem Fortschritt in der technischen Entwicklung im Bereich der MRT stehen auch in die Pferdemedizin Magnete mit Feldstärken von 3 Tesla zur Verfügung (Cavalleri et al. 2013, Gutierrez-Crespo et al. 2013, Hontoir et al. 2013). Die hohen Feldstärken schaffen neve Möglichkeiten und bringen Vorteile, wie eine höhere Auflösung, dünnere Schichtdicken und kürzere Aufnahmezeiten in einigen Sequenzen und Gewichtungen. Sie schaffen aber auch neve Herausforderungen (Merkle und Dale 2006, Chang et al. 2008). Der Bereich der equinen Nasenhöhlen, Nasennebenhöhlen und ihrer Verbindungen wurde bereits im MRT mit niedrigeren Feldstärken beschrieben (Arencibia et al. 2000, Gerlach et al. 2009). Ziel der vorliegenden Arbeit ist es die Vorteile der 3 Tesla-MRT zu nutzen um qualitativ hochwertige Bilder der Nasen- und Nasennebenhöhlen sowie umliegender Strukturen bei lebenden, gesunden Pferden zu erstellen und eine Grundlage für die Interpretation von MRT-Bildern erkrankter Pferde zu schaffen.

\section{Material und Methode}

Dreizehn gesunde Pferde verschiedener Rassen (7 Warmblüter, 2 Arabische Vollblüter, 3 Traber, 1 Andalusier) wurden im 3 Tesla-MRT untersucht. Die Pferdepopulation bestand aus 8 Stuten, 4 Wallachen und einem Hengst. Das Alter der Pferde lag zwischen 4 und 20 Jahren (Mittelwert \pm SA, 11,6 \pm 6,5). Alle Pferde waren zum Zeitpunkt der Untersuchung allgemeingesund und zeigten keine Anzeichen einer Erkrankung der Nasenhöhlen oder Nasennebenhöhlen. Die Studie wurde durch das Niedersächsische Landesamt für Verbraucherschutz und Lebensmittelsicherheit nach $\S 8$ des Tierschutzgesetzes genehmigt. Das Aktenzeichen lautet 33.9-42502-04$11 / 0592$.
Tremaine W. H., Dixon P. M. (2001) A long-term study of 277 cases of equine sinonasal disease. Part 1: details of horses, historical, clinical and ancillary diagnostic findings. Equine Vet. J. 33, 274-282

Waibl H. (2004) Atmungsapparat. In: R. Nickel, A. Schummer and E. Seiferle (eds) Lehrbuch der Anatomie der Haustiere. Stuttgart: Parey Verlag, 9, 223-307

Waibl H., Wilke M., Münster W. (2005) Arterien, Arteriae, Venen, Venae. In: R. Nickel, A. Schummer and E. Seiferle (eds) Lehrbuch der Anatomie der Haustiere. Stuttgart: Parey Verlag, 4, 74-276

Weishaupt D., Köchli V. D., Marincek B. (2009) Wie funktioniert MRI? Heidelberg: Springer Medizin Verlag, 6
Die Lagerung der Pferde für die magnetresonanztomographische Untersuchung erfolgte in Rückenlage mit einer gestrekkten Kopf-Hals-Position auf einem mobilen Patiententisch. Der Körper der Pferde wurde durch eine aufblasbare Matte gepolstert. Um den Kopf wurden Oberflächenspulen (Philips SENSETM FlexM ${ }^{\circledR}$ und Philips SENSETM FlexL ${ }^{\circledR}$; Philips Medical Systems, Best, Niederlande) mit dem kaudalen Rand auf Höhe der Orbita positioniert. Kopf und Spulen wurden durch ein evakuiertes Vakuumkissen in Position gehalten. Für die magnetresonanztomographischen Untersuchungen wurde der Magnetresonanztomograph Achieva ${ }^{\text {TM }}$ 3.0TX-Series ${ }^{\circledR}$ (Philips Medical Systems, Best, Niederlande) verwendet.

Bei allen Pferden wurden Aufnahmen mit einer T2-gewichteten Sequenz (T2w) mit Turbo Spin Echo (TSE) in dorsaler und transversaler Ausrichtung, einer protonengewichteten Sequenz (PDw) in transversaler Ausrichtung und einer T1-gewichteten Sequenz (TIw) mit Fast Field Echo (FFE) und isotropen Voxeln erstellt. Transversale und dorsale Schnittebene wurden anschließend für die T1-gewichtete Sequenz durch multiplanare Rekonstruktion berechnet. Die transversalen Schnittbildserien wurden orthogonal zum harten Gaumen und dem Nasenseptum ausgerichtet und die dorsalen Serien parallel zum harten Gaumen sowie orthogonal zum Nasenseptum. Jede magnetresonanztomographische Untersuchungen wurden bei den Pferden jeweils mit denselben Einstellungen durchgeführt (Tab 1). Bei allen Pferden und in allen Sequenzen wurde versucht den Kopf des Tieres von den Augäpfeln bis zu den ersten prämolaren Backenzähnen darzustellen.

Alle magnetresonanztomographisch erstellten Bilder wurden im Anschluss systematisch betrachtet und ausgewertet. Die transversalen Schnittbildserien wurden von kaudal nach kranial gesichtet und die dorsal ausgerichteten Schnittbildserien wurden von dorsal nach ventral gesichtet. Ausgewertet wurden die am prominentesten und am vollständigsten dargestellten anatomischen Strukturen, wie das Siebbein, die Nasennebenhöhlen, die Apertura nasomaxillaris, die Canales infraorbitales mit ihrem Inhalt, die Venenplexus der Nasenschleimhaut sowie die prämolaren und molaren Oberkieferbackenzähne. Im Zuge der Betrachtung wurde die Darstellung der verschiedenen anatomischen Strukturen in den verschiedenen Sequenzen beurteilt und Ähnlichkeiten und Unterschiede zwischen den Sequenzen dokumentiert. Auch interindividuelle Unterschiede und Übereinstimmungen in der Dar- 
stellung sowie intraindividuelle Unterschiede im Seitenvergleich wurden erfasst. Zusätzlich wurde die Dicke der Venenplexus der Nasenschleimhaut an definierten Positionen in transversal ausgerichteten T2-gewichteten Bildern gemessen. Von jedem Pferd wurden vier Schnittbilder von vier Schnittebenen anhand von definierten anatomischen Strukturen ausgewählt (Abb. 1 bis 4).

Die Dicke der Nasenschleimhaut und Venenplexus entlang des Nasenseptums wurde in allen vier Schnittebenen auf Höhe des mittleren Nasenganges (Abb. 1 bis 4, rote Linien) orthogonal zum Nasenseptum gemessen. Entlang der ventralen Nasenmuschel fanden die Messungen an der Spitze der nach medioventral ragenden Spirallamelle am dicksten Punkt der Venenplexus statt (Abb. 2 und 3, grüne Linien). In Ebene 4 wurden die Messungen von der Spitze der Spirallamelle ausgehend zum am weitesten ventral gelegenen Punkt des ventralen Nasenganges vorgenommen (Abb. 4, grüne Linien). In Ebene 2 wurde die Messung der Dicke von Nasenschleimhaut und Venenplexus, welche der dorsalen und ventralen Nasenmuschel aufliegen, auf Höhe der Schnittstelle des gemeinsamen und mittleren Nasenganges vorgenommen. Weitere Messungen wurden auf halber Strecke zwischen der zuvor genannten Schnittstelle und einem von der Spirallamelle der dorsalen Nasenmuschel nach dorsal ragenden Vorsprung vorgenommen (Abb. 2). Alle Messungen wurden links und rechts vergleichend durchgeführt. Bildbetrachtung und Messungen wurden mit Hilfe des Betrachtungsprogramms eFilm Workstation ${ }^{\circledR}$ 1.5.3 (eFilm Medical, Toronto, Kanada) vorgenommen.

\section{Statistische Auswertung}

Die Daten wurden in tabellarischer Form mit Hilfe des Programms Office Excel $2003^{\circledR}$ (Microsoft Corporation, Redmond, WA, USA) gesammelt und deskriptiv ausgewertet.

\section{Ergebnisse}

Die MRT-Untersuchung des gewünschten Untersuchungsbereichs war bei allen 13 Pferden möglich. Die Untersuchungszeiten lagen zwischen 90 und $104 \mathrm{~min}$ (Mittelwert $100 \mathrm{~min}$ ). Das field of view (FOV) von kaudal nach rostral lag bei den dorsal ausgerichteten Schnittbildserien zwischen 260 und $300 \mathrm{~mm}$ (Mittelwert \pm SA; 277,6 mm $\pm 8,3 \mathrm{~mm}$ ) und zwischen 217 und $300 \mathrm{~mm}$ (Mittelwert $\pm S A ; 245,1 \mathrm{~mm} \pm 27,0 \mathrm{~mm}$ ) bei den transversal ausgerichteten Schnittbildserien. Die Bilder eines Pferdes mussten von den Messungen ausgeschlossen werden, da Bewegungsartefakte genave Messungen nicht zuließen. Das Aussehen der verschiedenen anatomischen Strukturen wird im Folgenden beschrieben.

\section{Das Siebbein}

Im Zentrum des Siebbeins war der dünne Schleimhautüberzug der Turbinalia als signalreiche, feine Linien sichtbar. Insbesondere in den T2-gewichteten Aufnahmen mit einer hohen Bildauflösung war das Siebbeinlabyrinth als feines Netzwerk aus kleinen Kanälchen sichtbar (Abb. 5). Die rostralen und ventralen Ränder des Siebbeins stellten sich bei allen Pferden und in allen Sequenzen verwaschen dar, so dass das beschriebene Netzwerk in diesem Bereich als solches nicht mehr erkennbar war.

\section{Die Nasennebenhöhlen}

Die Sinus conchofrontales, die Sinus maxillares rostrales und caudales, sowie die Sinus conchae ventrales waren alle als signalloser Bereich sichtbar, der von einer dünnen, sich signalreich darstellenden Schleimhaut umgeben war (Abb. 6). Die dünne, signalreiche Schleimhaut grenzte sich nach außen gegen den signallosen, kompakten Knochen ab. Dies war in den T2-gewichteten und protonengewichteten Sequenzen am deutlichsten zu erkennen. Eine Abgrenzung der Schleimhaut zu den Zahnfächern und den Spirallamellen der dorsalen und ventralen Nasenmuscheln war nur selten möglich.

Das Septum intermaxillare, welches die rostrale von der kaudalen Kieferhöhle trennt, wurde durch seinen rostralen und kaudalen, signalreichen Schleimhautüberzug sichtbar. Der Knochen, welcher das eigentliche Septum bildet, konnte nicht abgegrenzt werden. In den dorsal ausgerichteten Sequenzen stellte sich der Schleimhautüberzug der intermaxillären Septen als transversal verlaufende, verwaschene, signalreiche Linie dar, welche dorsoventral über die gesamten Sinus maxillares zu verfolgen war. In den transversal ausgerichteten Sequenzen war der Schleimhautüberzug der Septen als eine von medial nach lateral verlaufende, verwaschene, signalreiche Linie innerhalb der Sinus maxillares zu erkennen. Von kaudal war diese signalreiche Linie ab der Höhe der Canales infraorbitales zu erkennen. Je weiter rostral die transversale Schnittebene des Bildes lag, desto weiter ventral war lag der Anschnitt der intermaxillären Septen. Sie endete schließlich auf dem Boden der Sinus maxillares rostrales.

Die Septen der Nasenmuscheln waren ebenfalls als transversal verlaufende, signalreiche Linien in den dorsal ausgerichteten Sequenzen erkennbar. Die intermaxillären und die conchalen Septen waren in allen dorsal orientierten Sequenzen zu erkennen. Bei einem Anschnitt eines Nasenmuschelseptums in einem transversalen Schnittbild, stellte sich dieses als signalreiche unterbrochene Linien dar, welche die jeweilige Nasenmuschel ausfüllten. Das Aussehen dieser Septen entsprach dem der intermaxillären Septen. Bei drei Pferden wurden geringe Mengen hyperintenser Flüssigkeit in den Nasennebenhöhlen dargestellt. Bei einem Pferd befand sich diese im Sinus frontalis und bei den beiden anderen Pferden im rechten Sinus conchae ventralis. Die Schleimhaut der Nasennebenhöhlen und die Flüssigkeit konnten in diesen Fällen nicht voneinander abgegrenzt werden, da sie die gleiche Signalintensität aufwiesen. Die Flüssigkeit war dennoch als solche zu erkennen, da ein klarer Spiegel vorlag (Abb. 7). Bei einem Pferd wurde verdickte Schleimhaut auf einer rostrokaudalen Ausdehnung von ca. 1,5 cm am Boden des rechten Sinus conchae ventralis dargestellt.

\section{Die Apertura nasomaxillaris}

Der mittlere Nasengang war in allen Sequenzen klar abgegrenzt zu erkennen. Der laterale Verlauf der Apertura nasomaxillaris mit ihrem Ursprung im mittleren Nasengang und der dorsokonvexen Form war ebenfalls in allen transversal ausgerichteten Sequenzen zu erkennen. Die dorsale Begrenzung der Apertur war eindeutig der Spirallamelle der dorsalen Nasenmuschel und die ventrale Begrenzung eindeutig der Spirallamelle der ventralen Nasenmuschel zuzuordnen. Das Lumen der Apertur, welches in die Sinus maxillares rostrales 
und caudales führt, konnte in keiner der transversal ausgerichteten Sequenzen dargestellt werden. Die Schleimhaut, welche die dorsale und ventrale Begrenzung des Lumens der Apertur bildet, stellte sich als verwaschene, signalreiche Linie dar, welche sich an einigen Punkten so weit annäherte, dass kein Lumen mehr zu erkennen war (Abb. 8). Dieses Bild wiederholte sich in allen transversal orientierten Sequenzen. In den dorsal orientierten Sequenzen konnte die Apertur in keinem der Schnittbild dargestellt werden.

\section{Der Canalis infraorbitalis und Nervus infraorbitalis}

In den transversal orientierten Sequenzen stellte sich der Knochen der Canales infraorbitales als ein signalloser Ring innerhalb des signallosen Raums der Sinus maxillares rostralis und caudalis dar. Optisch abgrenzbar wird der Knochen des Kanals durch die signalreiche Schleimhaut, welche ihn als Teil der Nasennebenhöhlenschleimhaut auf der sinuswärtigen Wand überzieht. Die Form des Kanals unterschied sich von kaudal nach rostral und interindividuell. In den Bereichen, wo der Kanal nicht in direktem Kontakt zu den Zahnfächern der Oberkieferbackenzähne stand, wurde er durch eine vertikal verlaufende signallose Knochenplatte in Position gehalten. In diesem Fall hatte der Kanal bei zehn Pferden einen längsovalen Querschnitt, der sich der Form eines Luftballons ähnelt. Bei zwei Pferden stellte sich der Querschnitt des Kanals polygonal dar. Bei einer 20-jährigen Warmblutstute unterschied sich die Form der Canales infraorbitales beider Seiten. Auf einer Seite lag die beschriebene Ballonform vor, während der Kanal der anderen Seite einen dorsoventral abgeflachten, querovalen Querschnitt aufwies. Bei sieben Pferden hatten die Canales infraorbitales direkten Kontakt zu einer unterschiedlichen Anzahl von Zahnfächern der Oberkieferbackenzähne. Bestand ein direkter Kontakt zu den Zahnfächern, war die Form des Kanals irregulär und der Form des Zahnfachs angepasst (Abb. 9).

Die Position des Kanals im Bezug zu umliegenden anatomischen Strukturen wies altersabhängige Unterschiede auf. Abhängig vom Alter des Pferdes bestand ein direkter Kontakt des Kanals zu einer unterschiedlichen Anzahl von Zahnfächern der Oberkieferbackenzähne (Tab. 2). Bei zwei Pferden lagen die Canales infraorbitales beider Seiten nicht auf der gleichen dorsoventralen Höhe. Es lag ein Unterschied von 4 bis $6 \mathrm{~mm}$ vor. In den Bereichen, wo der Kanal nicht in direktem Kontakt mit einem Zahnfach stand, konnte in einigen transversalen Schnittbildern eine dünne Linie mit hoher bis moderater Signalintensität dargestellt werden, welche ihren Ursprung im Inneren des Kanals besaß und am Apex eines der Zahnfächer endete (Abb. 10).

Das Weichteilgewebe im Inneren des Kanals konnte als eine inhomogene Komposition mit hoher bis moderater Signalintensität dargestellt werden. Ein Großteil des Lumens des Kanals wurde durch den Nervus infraorbitalis eingenommen, welcher eine moderate Signalintensität aufwies. Die Form des Nerven passte sich der des Kanals an. Dem Nerven anliegend waren in den meisten transversalen Schnittbildern Blutgefäße zu sehen, welche sich als signalloser oder signalreicher Punkt darstellten (Abb. 9). In einigen transversalen Schnittbildern stellten sich der Kanal und der Inhalt als verzerrt dar, was eine deutliche Unterscheidung der einzelnen Strukturen nicht zuließ. Im Bereich des Foramen infraorbitale, wo der knöcherne Canalis infraorbitalis endet, legte sich der Nervus infraorbitalis dem Knochen von lateral flach an.

Die transversal ausgerichteten Sequenzen mit einer hohen Bildauflösung, also die T2- und protonengewichtete Sequenzen, stellten den Canalis und Nervus infraorbitalis am besten dar. Die transversal ausgerichtete T1-gewichtete Sequenz ließ keine deutliche Unterscheidung zwischen knöchernem Kanal und dem Inhalt zu.

\section{Das Septum nasale}

Das Nasenseptum stellte sich bei den dreizehn Pferden unterschiedlich dar. Bei sechs Pferden (4 bis 7 Jahre alt) war es in seinem dorsoventralen und kaudorostralen Verlauf homogen und hatte eine moderate Signalintensität (Abb. 11 a). Bei drei Pferden (14 bis 20 Jahre alt) erschien das Nasenseptum zweigeteilt mit einem signalreichen dorsalen Anteil und einem ventralen Teil mit moderater Signalintensität (Abb. 11 b). Diese unterschiedlichen Anteile waren durch eine signallose, transversal verlaufende Linie getrennt und beide Anteile wurden durch eine signallose, dünne Linie umrandet. Bei vier Pferden (7 bis 19 Jahre alt) war sowohl das homogene als auch das geteilte Erscheinungsbild vorhanden. In diesen Fällen stellte sich der rostrale Anteil des Septums als homogen mit moderater Signalintensität dar und der kaudale Anteil wies die oben beschriebene Zweiteilung auf. Bei drei dieser Pferde bestand die Zweiteilung ab der Höhe der M2 und bei einem Pferd ab der Höhe des M3 nach kaudal. Die Sequenzen mit einer hohen Bildauflösung stellten die dorsoventrale Zweiteilung der Nasensepten mit einer hohen Genauigkeit dar. Bei neun Pferden (5 bis 20 Jahre alt) lag entweder eine geringgradige Deviation des Nasenseptums nach links oder rechts, eine dorsoventral verlaufende, sigmoide Deviation oder eine Kombination dieser beiden Deviationen vor. Bei vier Pferden (4 bis 7 Jahre alt) lag keine Deviation des Nasenseptums vor. Die beschriebenen Variationen des Nasenseptums konnten in allen transversal ausgerichteten Sequenzen dargestellt werden.

\section{Die Venenplexus der Nasenschleimhaut}

Zusätzlich zu der detaillierten Beschreibung der Darstellung der Venenplexus, wurde die Dicke der Venenplexus der Nasenschleimhaut in 48 transversalen, T2-gewichteten Schnittbildern gemessen. Die Schnittbilder eines Pferdes konnten für die Messungen nicht herangezogen werden, da exakte Messungen durch Bewegungsartefakte nicht möglich waren. Bei allen 13 Pferden nahmen die Venenplexus der Nasenschleimhaut den Großteil des Lumens der Nasenhöhle ein. Bei vier Pferden waren alle vier Nasengänge durch Schleimhaut und Venenplexus verlegt (Abb. 12). Bei neun Pferden waren die Nasengänge mit einem schlitzförmigen Lumen von 1 bis $4 \mathrm{~mm}$ erhalten. Es lagen keine Unterschiede der Größe des Lumens im Links-Rechts-Vergleich vor. In den transversalen Schnittbildern stellten sich die Venenplexus der Nasenschleimhaut als ein Zusammenschluss aus mehreren Venulen dar. Die einzelnen Venulen besaßen eine runde bis ovale Form und waren in den transversalen T2-gewichteten und protonengewichteten Schnittbildern deutlich zu differenzieren. In den T2-gewichteten Schnittbildern stellten sich einige Venulen als homogene Strukturen mit einer hohen Signalintensität dar, während andere eine dorsoventrale Zweiteilung 
aufwiesen. In diesen Fällen wies die ventrale Hälfte eine hohe Signalintensität auf, während die dorsale eine moderate bis keine Signalintensität besaß (Abb. 11 b). Dieses Erscheinungsbild konnte auch in den protonengewichteten, transversalen Schnittbildern nachvollzogen werden. Ein drittes Erscheinungsbild der einzelnen Venulen war ausschließlich in T2gewichteten, transversalen Schnittbildern aufzufinden. In diesem Fall besaßen die einzelnen Venulen ein rundes Zentrum mit geringer Signalintensität, welches von einem signalreichen, kreisförmigen Bereich umgeben war. Unabhängig von ihrem Erscheinungsbild waren alle Venulen durch eine dünne, signallose Linie voneinander getrennt.

Die oben beschriebenen Erscheinungsbilder der Venulen konnten in den transversalen, T1-gewichteten Schnittbildern nicht nachvollzogen werden. Die Venenplexus waren hier als homogene, isointense Flächen zu erkennen. Nur in wenigen transversalen Schnittbildern waren die Venulen als einzelne Strukturen zu erkennen, die die gleiche, oben beschriebene Form besaßen und homogen mit einer moderaten bis hohen Signalintensität erschienen. In den dorsalen Schnittbildern waren die Venenplexus als Strukturen mit einer hohen Signalintensität zu erkennen. In einigen Schnittbildern konnten die einzelnen Venulen der Venenplexus in ihrem kaudorostralen Verlauf dargestellt werden. Sie erschienen als signalreiche, geschwungene Stränge, die durch dünne, signallose Linien voneinander getrennt waren (Abb. 13). Aus dem Erscheinungsbild der Venulen in den transversalen Schnittbildern kann man schließen, dass die Venulen als schlauchartige Strukturen von rostral nach kaudal ziehen.

In den transversalen Schnittbildern waren die am weitesten kaudal gelegenen Venenplexus auf einer Schnittebene zu sehen, die direkt rostral des Siebbeins lag. Diese Venenplexus legten sich in einer U-Form von ventral um den Vomer und das Nasenseptum. Unmittelbar rostral dieser Stelle waren auch die ersten Venenplexus zu erkennen, die die Spirallamellen der kaudalen Nasenmuscheln säumen. Sie ragten in die Lumina der ventralen Nasengänge hinein. Die Venenplexus, welche die Spirallamelle der dorsalen Nasenmuschel säumen, waren ab dem kaudalen Beginn der Spirallamelle zu sehen.

Im rostralen Verlauf verloren die Venenplexus, die dem Vomer und dem Nasenseptum anliegen, ab dem Punkt ihre U-Form, an dem die Choanen enden und der Vomer Anschluss an die Sutura palatina findet. Die Venenplexus lagen ab diesem Punkt dem Septum von lateral weiterhin beiderseits an und erstreckten sich im ventralen Bereich nach lateral, wo sie unter der Schleimhaut des Bodens des ventralen Nasenganges lagen. Der Median der gemessenen Dicke der Nasenschleimhaut und der Venenplexus im Bereich des Nasenseptums (Abb. 1 bis 4, rote Linien) lag bei 8,38 $\mathrm{mm}$ mit einer Spannweite von 2,92 mm bis $16,46 \mathrm{~mm}$ (Tab. 3). Nur eine Schicht an Venulen lag unter der Schleimhaut des ventralen Nasenganges. Die Schleimhaut des ventralen Nasenganges oberhalb der Venenplexus bestand aus einer dicken Gewebeschicht, die sich in T2-gewichteten Schnittbildern isointens und in T1-gewichteten Schnittbildern hypointens darstellte.

In dem dargestellten rostrokaudalen Bereich war der dorsale Anteil des Nasenseptums beiderseits nicht von Venenplexus bedeckt. Die Venenplexus nahmen ab der Höhe des mittleren Nasenganges nach dorsal hin an Dicke ab, bis sie schließlich nicht mehr sichtbar waren und nur noch ein Schleimhautüberzug bestand. Die Venenplexus des rostralen Teils des Nasenseptums wurden nach ventral dünner bis sie im ventralen Bereich nicht mehr vorhanden waren und nur noch der mittlere Anteil des Nasenseptums von Venenplexus bedeckt war. Dies war ab einer Ebene auf der Höhe der Foramina infraorbitalia nach rostral zu erkennen. Auf der gleichen Höhe verschwand auch das oben beschriebene Gewebe am Boden des ventralen Nasenganges. Nur ein dreieckiger Bereich zwischen dem Boden des ventralen Nasenganges und dem Nasenseptum wurde beiderseits von Venenplexus gefüllt.

Die Venenplexus der ventralen Nasenmuschel waren von kaudal nach rostral auf der ganzen Länge des dargestellten Bereichs vorhanden. In einigen Bereichen bestanden die Venenplexus aus bis zu fünf Schichten von Venulen, an anderen nur aus einer Schicht. Die Dicke der Venenplexus änderte sich von kaudal nach rostral ohne erkennbare Regelmäßigkeit. Die gemessene Dicke der Nasenschleimhaut und ihrer Venenplexus im Bereich der Spirallamelle der ventralen Nasenmuschel (Abb. 2 bis 4, grüne Linien) lag bei 14,41 mm mit einer Spannweite von 7,20 mm bis 25,50 mm (Tab. 3). Die Venenplexus, die der dorsalen Nasenmuschel auflagen, waren nicht so dick, wie die der ventralen Nasenmuschel und setzten sich nur aus einer Schicht von Venulen zusammen, die in ihrer Dicke variierte.

Der Anteil des mittleren Nasenganges, welcher in die Apertura nasomaxillaris führt, war ebenfalls nur von einer einzelnen Schicht an Venulen bedeckt. Die Dicke der Venulen nahm von medial nach lateral in Annäherung an die Apertura nasomaxillaris ab, bis nur noch Schleimhaut vorhanden war. Die gemessenen Dicken der Schleimhaut und Venenplexus des mittleren Nasenganges (Abb. 2, dl, dm, vl, vm) sind aus Tabelle 3 ersichtlich.

\section{Die Oberkieferbackenzähne}

Bei allen untersuchten Pferden waren 6 permanente Oberkieferbackenzähne vorhanden. Sie konnten in allen Sequenzen und Ausrichtungen dargestellt werden. Die Längen der Zähne unterschieden sich von Pferd zu Pferd, was im altersabhängigen Abrieb der Zähne begründet liegt. Die Pulpa der Zähne war bei allen Pferden von apikal nach okklusal mit einer hohen Signalintensität in den T2- und protonengewichteten Schnittbildern zu erkennen. In den T1-gewichteten Schnittbildern besaß sie eine moderate bis hohe Signalintensität. Das gesamte Ausmaß der Pulpa war am besten in den dorsalen, T2-gewichteten Schnittbildern zu erkennen. Dentin, Schmelz und Zahnzement der Oberkieferbackenzähne erschienen signallos und waren nicht voneinander abgrenzbar. Die Reservekrone der Backenzähne war gegen das periodontale Ligament abgrenzbar, welches als eine dünne, helle Linie den Zahn umgab. In einigen Schnittbildern war das helle periodontale Ligament von einer signallosen, dünnen Linie umgeben, welche den kompakten Knochen des Zahnfachs (Lamina dura) widerspiegelte. Abhängig von der Position des Zahns, waren die Wurzeln der Oberkieferbackenzähne entweder von signalreichem, markhaltigem Knochen oder signallosem, kompaktem Knochen umgeben.

Das Zahnsäckchen, welches die Reservekrone von wachsenden Zähnen umgibt, war bei drei Pferden (Alter: 4 bis 5 Jahre) 
vorhanden. Die Reservekronen der M3 waren bei allen drei Pferden von einem signalreichen Saum umgeben, welcher sich gegen den umliegenden, signallosen Knochen abhob. Dieses Bild war ebenfalls bei den P4 von einem fünfiährigen Pferd sowie bei den P3 und P4 eines vierjährigen Pferdes vorhanden (Abb. 14).

\section{Diskussion}

In der vorliegenden Studie wurden unter Anwendung eines 3 Tesla Magnetresonanztomographen Schnittbildserien der Nasen- und Nasennebenhöhlen von 13 gesunden Pferden erstellt. Die Bilder konnten bei allen 13 Pferden erstellt werden. Ein erfolgreicher Ablauf der Untersuchungen kann nicht für Pferde aller Rassen und Größen angenommen werden. Die Bauweise des Philips Achieva ${ }^{\text {TM }}$ 3.0TX-Series ${ }^{\circledR}$ (Philips Medical Systems, Best, Niederlande) birgt für die Lagerung einiger Pferde Probleme. Die Röhre des Magnetresonanztomographen hat eine Tiefe von $167 \mathrm{~cm}$ und einen Durchmesser der Röhrenöffnung von $60 \mathrm{~cm}$. Körperteile, die untersucht werden sollen, müssen im Zentrum der Röhre gelagert werden. Zusammengenommen bedingen diese Eigenschaften, dass der Kopf von Pferden mit einem sehr dicken und/oder sehr kurzen Hals nicht im Zentrum der Röhre positioniert werden können.

Die Qualität der Schnittbilder variierte von Pferd zu Pferd, auch wenn ein standardisiertes Protokoll an Sequenzen angewandt wurde. Diese Variationen entstehen durch verschiedene Variablen, die neben dem Sequenzprotokoll vorliegen. Bei den verwendeten Empfängerspulen handelt es sich um flexible Oberflächenspulen, die um den Kopf des Pferdes gelegt wurden. Sie ermöglichen ein Untersuchungsfeld mit einer Länge von ca. $30 \mathrm{~cm}$. Geringe Fehlpositionierungen der Spulen können zu einem Verlust von Signal in den Randbereichen des Sichtfeldes führen. In diesem Fall wurde der Processus zygomaticus des Os temporale als anatomischer Orientierungspunkt gewählt und die Oberflächenspulen (Philips SENSETM FlexM ${ }^{\circledR}$ und Philips SENSETM FlexL ${ }^{\circledR}$; Philips Medical Systems, Best, Niederlande) mit ihrem kaudalen Rand auf diesem Processus positioniert. Diese Einschränkungen in Bezug auf die Größe des Sichtfeldes bedingten eine vollständige Abbildung der Nasen- und Nasennebenhöhlen nur bei Pferden mit kleinen Köpfen.

Das Ziel der Studie war es die Nasen- und Nasennebenhöhlen darzustellen. Das eingeschränkte Sichtfeld verhinderte eine vollständige Abbildung des gesamten Kopfes. Kaudale Anteile der Sinus conchofrontalis und sphenopalatinus sowie rostrale Anteile der Nasenhöhle konnten nicht abgebildet werden. Diese Einschränkung der MRT muss bei der Positionierung des Patienten in der Röhre des Magneten und bei der Positionierung der Empfängerspulen um den zu scannenden Bereich des Kopfes berücksichtigt werden.

Die MRT ist anfällig für Artefakte, die durch Bewegungen des Patienten entstehen (Weishaupt et al. 2009). Diese Bewegungsartefakte können durch physiologische Bewegungen, wie den Herzschlag oder die Atemaktivität bedingt sein (Murray und Dyson 2007). In der vorliegenden Untersuchung lagen störende Bewegungsartefakte bei einem Pferd vor. Diese Artefakte entstanden durch eine medikamentös induzierte Tachykardie nach einer Bolusinjektion von 0,01 mg Atropin/kg
Körpergewicht, die das Pferd aufgrund einer Bradykardie während der Allgemeinanästhesie erhielt.

Die Nasenhöhlen ließen sich in den magnetresonanztomographischen Schnittbildern sehr gut und detailliert darstellen, da der große Gehalt an Weichteilgewebe in Form der Venenplexus der Nasenschleimhaut einen guten Kontrast erzeugte. Die Nasennebenhöhlen werden als luftgefüllte Höhlen, die von Schleimhaut ausgekleidet sind, beschrieben (Waib) 2004, Salomon 2008). Da Luft zu wenige Protonen enthält, um ein Signal in der MRT erzeugen zu können, erscheint diese in den Schnittbildern als schwarzer bzw. signalloser Bereich. Auch kompakter Knochen erscheint in der MRT schwarz bzw. signallos (Weishaupt et al. 2009). Dies führt dazu, dass in den Bereichen, wo Knochen und Luft direkt aneinander grenzen nur durch die dünne Schleimhautauskleidung eine Begrenzung der Nasennebenhöhlen möglich ist. In allen erzeugten Schnittbildern waren die Nasennebenhöhlen durch die signalreiche, helle Schleimhaut deutlich einzugrenzen. Dadurch konnte kompakter Knochen von lufthaltiger Nasennebenhöhle differenziert werden. Bei entzündlichen Veränderungen der Nasennebenhöhlen ist eine Verdickung der Schleimhaut zu erwarten (Tremaine und Dixon 2001, Bienert 2002).

Bei drei Pferden wurde Flüssigkeit in den Nasennebenhöhlen dargestellt. Diese Flüssigkeit konnte aufgrund derselben Signalintensität nicht von der Schleimhaut unterschieden werden. In klinischen Fällen, in denen sich Flüssigkeit in den Nasennebenhöhlen befindet, kann es daher nur schwer oder gar nicht möglich sein, Flüssigkeit von geschwollener oder hypertropher Schleimhaut zu unterscheiden.

Bei einem Pferd, in dessen rechtem Sinus conchae ventralis Flüssigkeit vorlag, konnte im Bereich des Zahnfaches des rechten M1 Schleimhaut dargestellt werden, die seitenvergleichend eine Verdickung aufwies. Diese Verdickung kann als eine lokale Schwellung der Schleimhaut im Zusammenhang mit einer Entzündung angesehen werden. Die gleichseitige Flüssigkeitsansammlung könnte ebenfalls im Zusammenhang mit der Entzündung stehen und als Exsudat der entzündeten Schleimhaut gedeutet werden. Ein vergleichbarer Fall wurde in einer Studie von Gerlach et al. (2011) beschrieben.

Arencibia et al. (2000) und Gerlach et al. (2009) nutzten die MRT um eine Übersicht über die Darstellung anatomischer Strukturen des Pferdekopfes zu erstellen. Gerlach et al. (2009) verwendeten drei lebende Pferde und drei Pferdekopfpräparate. Arencibia et al. (2000) nutzten zwei Pferdekopfpräparate. Junker et al. (2002) untersuchten sechs Pferdekopfpräparate als Vergleichsgrundlage für verschiedene klinische Fälle. In der vorliegenden Studie wurden alle dreizehn Patienten lebend untersucht. Die Verwendung von Pferdekopfpräparaten eliminiert die oben beschriebenen Probleme der Lagerung innerhalb der Röhre des Magneten, da Hals und Körper nicht mehr an die Verkleidung des Magneten stoßen können. Es muß jedoch davon ausgegangen werden, dass es Unterschiede der Ergebnisse von in vivo und ex vivo MRT-Studien gibt. Die MRT gibt den Zustand eines Gewebes anhand der Verteilung und Bindung von Protonen wieder. In totem Gewebe führt der fehlende Blutfluss im Gewebe zu einer Veränderung des Protonengehalts. In diesem Zusammenhang ändert sich auch das Aussehen von Blutgefäßen, 
da Blutdruck und Durchstrom von Blut fehlen. Bei der Untersuchung von lebenden Geweben führt der Blutstrom zu dem sogenannten Outflow-Effekt, bei dem Blutgefäße mit einer niedrigen Signalintensität oder signallos dargestellt werden (Weishaupt et al. 2009). Des Weiteren führt der Mangel an Blutfluss und Blutdruck zu einer anderen Darstellung von erektilen Geweben, wie den Venenplexus der Nasenschleimhaut, da diese abschwellen. Die Venenplexus erscheinen im toten Gewebe dünner als im lebenden und die Nasengänge haben dadurch ein weiteres Lumen (Arencibia et al. 2000; Gerlach et al. 2009).

Arencibia et al. (2000) und Gerlach et al. (2009) nutzten Magneten mit einer Feldstärke von 1,5 Tesla während Junker et al. (2002) einen Magneten mit einer Feldstärke von 0,2 Tesla nutzten. Ein Magnet mit einer Feldstärke von 3 Tesla bietet Vor- und Nachteile gegenüber Magneten mit geringeren Feldstärken. Das stärkere Magnetfeld ermöglicht ein höheres Signal-Rausch-Verhältnis, was wiederum eine höhere Bildauflösung ermöglicht. Besonders in T2-gewichteten Sequenzen kann das höhere Signal-Rausch-Verhältnis für eine schnellere Bilderzeugung genutz† werden, während die Qualität und Auflösung der Bilder mit denen von schwächeren Magneten vergleichbar bleibt (Merkle und Dale 2006, Chang et al. 2008; Weishaupt et al. 2009). Diese Eigenschaft ist besonders im Zusammenhang mit einer kürzeren Allgemeinanästhesie bei der Untersuchung von Pferden erwünscht. Bei T1-gewichteten Spin-Echo-Sequenzen sind die Untersuchungszeiten bei Hochfeldmagneten länger als bei Magneten niedrigerer Feldstärken, da die T1-Relaxationszeit bei 3 Tesla verlängert ist (Merkle und Dale 2006, Chang et al. 2008, Weishaupt et al. 2009).

Weitere Nachteile der hohen Feldstärke liegen in einer höheren Anfälligkeit für Suszeptibilitätsartefakte, Chemical-ShiftArtefakte und Standing-Wave-Artefakte (Merkle und Dale 2006, Chang et al. 2008). Die Verkürzung der Untersuchungszeit, die mit einem 3 Tesla Magnetresonanztomographen erreicht werden kann, ist begrenzt, da die emittierten Radiowellen eine höhere Energie aufweisen und zu einer Erwärmung der zu untersuchenden Gewebe führen. Die Energie der Radiowellen in einem 3 Tesla-Magneten ist im Vergleich zu einem 1,5 Tesla-Magneten vervierfacht (Chang et al. 2008).

In der vorliegenden Studie wurde das höhere Signal-RauschVerhältnis für die Aufnahme von T2- und protonengewichteten Schnittbildserien mit einer hohen Qualität genutzt. Dies ermöglichte eine detaillierte Darstellung von feinen Strukturen, wie dem Siebbein, den Nervi infraorbitales, dem periodontalen Ligament und den Venulen der Venenplexus der Nasenschleimhaut.

In anderen MRT-Studien wurden T1-gewichtete Sequenzen genutzt um eine anatomische Darstellung von Strukturen zu erreichen (Arencibia et al. 2000, Busoni et al. 2005, Mair et al. 2005). In unserer Studie waren T2-gewichtete Sequenzen den T1-gewichteten Sequenzen im Bezug auf die anatomische Darstellung deutlich überlegen. Bei einer längeren Untersuchungszeit würden die T1-gewichteten Sequenzen in der 3 Tesla-MRT vermutlich zu vergleichbar guten Ergebnissen kommen.
In einigen Bereichen zeigten die sonst deutlich abgegrenzten Strukturen ein verwaschenes und verzerrtes Bild. Dies konnte im Bereich des Septum intermaxillare und auf transversalen Schnittbildern im Bereich der Apertura nasomaxillaris gesehen werden. Diese Unregelmäßigkeiten stellten sich bei allen Pferden dar und sind nicht als Pathologien anzusehen. Es gibt zwei Gründe für die verwaschene Darstellung dieser Strukturen. Zum einen liegt dies an der Ausrichtung der Schnittebenen. In dieser Studie wurden der harte Gaumen, seine Rugae palatinae und das Nasenseptum als anatomische Orientierungspunkte für die Ausrichtung der Schnittebenen gewählt. Die verschiedenen anatomischen Strukturen zeigen jedoch unterschiedliche Ausrichtungen im Verhältnis zu den gewählten Orientierungspunkten. Dies führt unausweichlich dazu, dass einige Strukturen nicht orthograd, sondern schräg angeschnitten werden. In klinischen Fällen sollten daher zusätzliche Schnittebenen erstellt werden, um eine pathologische Veränderung bzw. Verformung von Strukturen auszuschließen. Jede zusätzlich erstellte Ebene benötigt jedoch Zeit, die die Gesamtuntersuchungszeit verlängert. Der zweite Grund für das verwaschene Aussehen einiger feiner Strukturen ist der Partial-Volume-Effekt. Dieser Artefakt entsteht, wenn zwei Strukturen mit unterschiedlichen Eigenschaften in einem Voxel dargestellt werden und ihre Eigenschaften in diesem einen Voxel gemittelt werden (Weishaupt et al. 2009). Dieser Effekt kann vermieden werden, wenn man eine geringere Schichtdicke der Bilder wählt. Dies führt wiederum zu einer verlängerten Aufnahmezeit oder einem geringeren Signal-RauschVerhältnis und so zu einer schlechteren Qualität der Schnittbilder.

Gerlach et al. (2011) beschrieben bereits ein ähnliches Aussehen des Nervus infraorbitalis und der anliegenden Blutgefäße, wie in der vorliegenden Studie. Die hohe Auflösung der T2- und protonengewichteten Schnittbilder ermöglichte zusätzlich auf einigen Bildern die Darstellung einer feinen Linie mit moderater Signalintensität, die vom Canalis infraorbitalis ausgeht und zu den Wurzelspitzen der Oberkieferbakkenzähne führt. Diese feine Linie stellt Rami des Nervus infraorbitalis oder der Arterien und Venen dar, die die Oberkieferbackenzähne versorgen (Böhme 2004, Waibl et al. 2005).

In der Literatur wird beschrieben, dass die Venenplexus der Nasenschleimhaut aus bis zu fünf Schichten von Venulen aufgebaut sein können (Ackerknecht 1943). Die Gefäßwände der Venulen enthalten Sphinkter, die ihnen die Funktion eines erektilen Gewebes verleihen (Liebich 2004, Salomon 2008). Die Venulen der Nasenschleimhaut konnten bei allen 13 Pferden dargestellt werden. Die Venulen zeigten sich als gebündelte Pakete, die jedoch nicht in definierten Schichten organisiert waren. Bis zu fünf Venulen überlagerten sich von ihrer Unterlage ausgehend in Richtung des Lumen der Nasenhöhle. Dies stimmt mit den Beobachtungen von Ackerknecht (1943) überein. Bei allen 13 Pferden waren die Venenplexus zum Zeitpunkt der Untersuchung gefüllt bzw. geschwollen und das Lumen der Nasengänge auf ein Minimum reduziert.

In der Humanphysiologie wird beschrieben, dass einem Blutdruckanstieg in einer der Venae jugulares internae ein Anschwellen der gleichseitigen Venenplexus der Nasenschleimhaut folgt. Dieser Druckanstieg kann entweder durch einen mechanischen Druck von außen oder die Positionierung des Kopfes in einer tieferen Position im Verhältnis zum 
Herzen bedingt sein. Die niedrigere Position des Kopfes im Verhältnis zum Herzen kann in einer liegenden Position zustandekommen. So schwellen bei auf der Seite liegenden Personen die Venenplexus der unten liegenden Seite an, während die Venenplexus der oberen liegenden Seite abschwellen (Babatola 1998). Geht man davon aus, dass ähnliche Mechanismen auch in der Physiologie des Pferdes greifen, ist es wahrscheinlich, dass die Lagerung der Pferde in Rückenlage mit einer gestreckten Kopf-Hals-Position zu einem Drukkanstieg in beiden Jugularvenen geführt hat. Dies könnte wiederum zu einem parallelen Anschwellen der Venenplexus beider Seiten geführt haben.

Durch den vorgegebenen Versuchsablauf konnten die ersten Schnittbilder erst nach einer circa 20-minütigen Allgemeinanästhesie und Rückenlage erstellt werden. Zu diesem Zeitpunkt waren die Venenplexus beider Nasenhöhlen bereits geschwollen und ihr Zustand änderte sich nicht über den weiteren Verlauf der Untersuchung. Durch die hier beschriebenen Untersuchungen ist es nicht möglich zu bestimmen, wie schnell der Vorgang des Anschwellens der Venenplexus voranschritt.

Bei der MRT-Untersuchung von lebendem Gewebe stellen sich Blutgefäße durch den Outflow-Effekt ohne Signal dar (Weishaupt et al. 2009). Die Venenplexus aller 13 Pferde stellten sich hell und mit einer hohen Signalintensität dar. Dies lässt darauf schließen, dass das Blut in den Venulen der Venenplexus nicht in Bewegung ist, was entweder durch eine Kontraktion der gefäßeigenen Sphinkter oder eine hämodynamische Stase des Blutes bedingt ist. In diesen Fällen gibt das Blut viel Signal und erscheint hell (Weishaupt et al. 2009). Die beschriebenen unterschiedlichen Erscheinungsbilder der Venulen dürfen in klinischen Fällen nicht als pathologisch eingestuft werden.

Die Messung der Dicke der geschwollenen Venenplexus kann durch die Ausrichtung der Schnittebene und einen schrägen Anschnitt verfälscht sein. Die Venenplexus können so dicker erscheinen als sie wirklich sind. Um diesen Effekt zu meiden wurden in der vorliegenden Studie der harte Gaumen und das Nasenseptum als Orientierung gewählt, da die Venenplexus diesen in einem parallelen Verlauf folgen.

Ackerknecht (1943) beschreibt, dass die Venenplexus der Nasenschleimhaut im Bereich des ventralen Nasenseptums 5 $\mathrm{mm}$ dick sind. Er beschreibt nicht in welchem Zustand sich die Köpfe befanden (in vivo oder ex vivo) als die Messungen der Venenplexus vorgenommen wurden. In der vorliegenden Studie wurde die Dicke der Venenplexus, die dem Nasenseptum auf Höhe der mittleren Nasengänge anliegen, mit einem Maximum von 16,46 mm und einem Median von 8,38 mm gemessen. Ackerknecht (1943) beschreibt keine weiteren Werte für einen Vergleich.

Die veterinäranatomische Literatur gibt an, dass das Nasenseptum aus hyalinem Knorpel aufgebaut ist (König und Liebich 2005, Salomon 2008). Dieses konnte anhand der moderaten Signalintensität des Hauptanteils des Nasenseptums nachvollzogen werden. Es wird auch beschrieben, dass Teile des hyalinen Knorpels mit fortschreitendem Alter ossifizieren (Sisson 1914, König und Liebich 2005). Der signalreiche dorsale Anteil des Nasenseptums, der bei einigen Pferden dargestellt wurde, die eine dorsoventrale Zweiteilung des Septums aufwiesen, könnte ossifizierter Knorpel sein. Dieser besteht aus markhaltigem Knochen, der von kompaktem Knochen umrahmt wird. Eine Zweiteilung des Septums ist dementsprechend als physiologischer Zustand anzusehen. Es ist wahrscheinlich, dass die beschriebene Zweiteilung bei Pferden in fortgeschrittenem Alter auftritt. Bei vier Pferden (Alter: 7 bis 19 Jahre) zeigte der rostrale Anteil des Nasenseptums keine Ossifikation, während der kaudale Anteil des Nasenseptums die beschriebene Zweiteilung aufwies. Dies könnte bedeuten, dass die Ossifikation des Nasenseptums von kaudal nach rostral voranschreitet, da bei drei Pferden (Alter: 14 bis 20 Jahre) eine durchgehende Zweiteilung des Nasenseptums vorlag. Das Alter der untersuchten Pferde deutet auf einen altersbedingten Unterschied im Erscheinungsbild des Nasenseptums hin. Bei älteren Pferden ist eine Zweiteilung des Nasenseptums wahrscheinlicher. Um eine genauere Einschätzung der Altersabhängigkeit machen zu können, müßten Studien mit einer größeren Probandenzahl und einem Vergleich der MRT-Schnittbilder mit histologischen Untersuchungen erfolgen. Die hier beschriebenen Erscheinungsbilder des Nasenseptums sollten jedoch in klinisch relevanten Fällen nicht als pathologische Veränderungen gewertet werden.

Das beschriebene Aussehen der Oberkieferbackenzähne deckł sich mit den Ausführungen von Gerlach et al. (2011). Sie gaben an, dass eine dorsal ausgerichtete T2-gewichtete Sequenz die beste Übersicht über die Oberkieferbackenzähne bietet um pathologische Veränderungen aufzufinden. Diese Sequenz gab auch in der vorliegenden Studie die beste Übersicht über die gesamten Oberkieferbackenzähne.

\section{Schlussfolgerung}

Die vorliegende Studie zeigt und beschreibt das unterschiedliche Aussehen von anatomischen Strukturen im Bereich der Nasen- und Nasennebenhöhlen und ihrer Kommunikationswege in der Hochfeld-MRT mit einer Feldstärke von 3 Tesla. Die Ergebnisse der vorliegenden Studie können von Tierärzten, die mit der Hochfeld-MRT arbeiten, genutz† werden, um Schnittbilder auszuwerten und eine anatomische Orientierung zu erlangen. Auch physiologische, anatomische und individuelle Variationen sowie altersbedingte Unterschiede können mit Hilfe der Ergebnisse besser eingeschätz† werden.

Beim lebenden Patienten, der in Rückenlage und einer gestreckten Kopf-Hals-Position gelagert wird, liegt immer ein Anschwellen der Venenplexus der Nasenschleimhaut vor. Diese Ergebnisse erweitern das anatomisch-physiologische Verständnis über die Zustände der Nasenhöhlen des Pferdes, doch zeigen sie auch, dass weitere Untersuchungen mit einer größeren Zahl an Pferden nötig sind, um die diversen anatomischen Normvarianten zu erfassen und zu verstehen. 